\title{
Open-system magmatic evolution and crystallization conditions of the Ediacaran shoshonitic rocks from the São João do Sabugi Pluton, Borborema Province, NE Brazil
}

\author{
Dayvison Bruno Cordeiro de Paiva' (D), Frederico Castro Jobim Vilalva ${ }^{1 *}$ (D), Zorano Sérgio de Souza ${ }^{1}$ (D), \\ Marcos Antônio Leite do Nascimento' (1)
}

\begin{abstract}
The São João do Sabugi Pluton (SJSP) ( $\sim 579 \mathrm{Ma}$ ) is one of the most expressive occurrences of Ediacaran, syn- to post-collisional shoshonitic rocks in the Rio Piranhas-Seridó Domain, Borborema Province, NE Brazil. The petrography, whole rock and mineral composition of this pluton were investigated to characterize its open-system magmatic differentiation processes. The pluton is composed of three rock groups: gabbro-diorite, with clinopyroxene \pm orthopyroxene \pm amphibole \pm biotite; monzodiorite, with amphibole and biotite ( \pm pyroxenes); and granodiorite, with biotite as the main mafic mineral. Evidences of open-system processes, including partially resorbed metasediment xenoliths, are widespread. These rocks are metaluminous, alkali-calcic and magnesian, and have shoshonitic affinity. They show relative LILE and LREE enrichment and pronounced negative $\mathrm{Nb}$-Ta anomalies. Major and trace element geochemical modeling favors magma differentiation by fractional crystallization (56-62\%) after crustal assimilation of $\sim 30 \%$ of local paragneisses and schists from the Seridó Group in a relatively stationary magma chamber at crustal depth, under pressures of $5-6 \mathrm{kbar}$, temperatures of $\sim 800-1,000^{\circ} \mathrm{C}$ and relatively oxidizing conditions. The less evolved gabbro-diorite was generated by $\sim 18 \%$ modal dynamic partial melting of a metasomatized mantle source.
\end{abstract}

KEYWORDS: São João do Sabugi Pluton; geochemical modeling; open-system processes; shoshonite; Borborema Province.

\section{INTRODUCTION}

The transition between the Ediacaran and Cambrian in the Borborema Province, NE Brazil (Almeida et al. 1981), is marked by a voluminous and widespread, syn- to post-collisional, diverse plutonic magmatism (Jardim de Sá 1994, Angelim et al.2006, Nascimento et al.2000, 2015). In the northeastern part of the province, that comprises the Rio Piranhas-Serido (RPS) and São José do Campestre (SJC) tectono-structural domains, this magmatism encompasses batholiths, plutons, stocks, and dykes grouped into six distinct suites (Nascimento et al. 2015; Fig. 1):

- Shoshonitic (Shos);

- Porphyritic High-K Calc-Alkaline (PHKCalcAlk);

- Equigranular High-K Calc-Alkaline (EHKCalcAlk);

- Calc-Alkaline (CalcAlk);

- Alkaline (Alk);

- Charnockitic Alkaline (ChAlk).
The shoshonitic suite, formerly São João do Sabugi Intrusive Suite (Angelim et al. 2006), includes the less evolved lithotypes (Jardim de Sá 1994, Hollanda et al. 2003, Nascimento et al.2015). They occur mainly as enclaves into PHKCalcAlk, CalcAlk, and Alk types, frequently with mixing and mingling features (e.g., Antunes et al. 2000, Hollanda et al. 1999, Macedo Filho and Souza 2016, Chagas et al. 2018). Isolated shoshonitic plutons and stocks (e.g., Poço Verde, Casserengue, Riachão, and Rio Espinharas plutons; Fig. 1) are less common. They are composed of gabbro/diorite, monzodiorite, monzonite, and granodiorite, as well as minor granite and quartz syenite (Campos et al. 2002, Nascimento et al. 2002, 2015, Dias 2006, Guimarães et al. 2017). In particular, these isolated bodies are important sites for investigating the evolution and sources involved in the petrogenesis of these shoshonitic rocks.

Many Ediacaran ( $\sim 580 \mathrm{Ma})$, isolated shoshonitic bodies in the RPS and SJC domains are already well characterized from petrographic, structural, chemical, isotopic and geochronological data (e.g., Campos et al. 2002, Hollanda et al. 2003). Among these, one of the most important and expressive occurrences is the São João do Sabugi Pluton (SJSP), nearby the homonymous city in Rio Grande do Norte state. This pluton was dated at $579 \pm 7 \mathrm{Ma}$ (zircon U-Pb ID-TIMS; Leterrier et al. 1994) and studied by Jardim de Sá (1994), who provided structural, geochemical and isotopic information. Recently, Hollanda et al. (2003) presented Rb-Sr and Sm-Nd isotopic data for this pluton and other bodies of the shoshonitic suite and discussed the nature of the sources involved. Nevertheless, the São João do Sabugi rocks still lack detailed 
petrographic and chemical studies, as well as characterization of petrogenetic processes, crystallization conditions and tectonic setting involved. Of special interest, the SJSP bears multiple field and petrographic evidences pointing to open-system petrogenetic and evolutionary processes, which makes its study even more interesting. This paper reports petrographic and chemical evidence for the SJSP, including major and trace element geochemical modeling, that support differentiation processes from a basic magma involving assimilation of metasediments in a relatively stationary magma chamber.

\section{GEOLOGICAL FRAMEWORK}

The SJSP extends for $\sim 14 \mathrm{~km}$ in the NNE-SSW direction, near the cities of São João do Sabugi and Ipueira (Rio Grande do Norte State; Fig. 2). Nearby shoshonitic occurrences include the Rio Espinharas Pluton (Campos et al. 2002) and minor satellite bodies to the west, and the Boa Vista Stock (Paiva et al.2019) and minor bodies to the north (Figs. 1 and 2).

The SJSP geological setting comprises the RPS tectonic domain of the Borborema Province. The RPS is delimited to the south, east and west, respectively, by the Patos, Picuí-João Câmara and Portalegre Shear Zones; the northern boundary is covered by the Phanerozoic Potiguar Basin (Fig. 1). The basement consists of Rhyacian metavolcano-sedimentary rocks, orthogneisses and migmatites of the Caicó Complex, and augen gneisses from the Poço da Cruz Suite (ages between 2.25-2.11 Ga; Souza et al. 2007, 2016, Hollanda et al. 2011, and references therein), as well as Siderian orthogneisses and migmatites from the Arabia Complex ( 2.46 Ga; Costa and Dantas 2018).

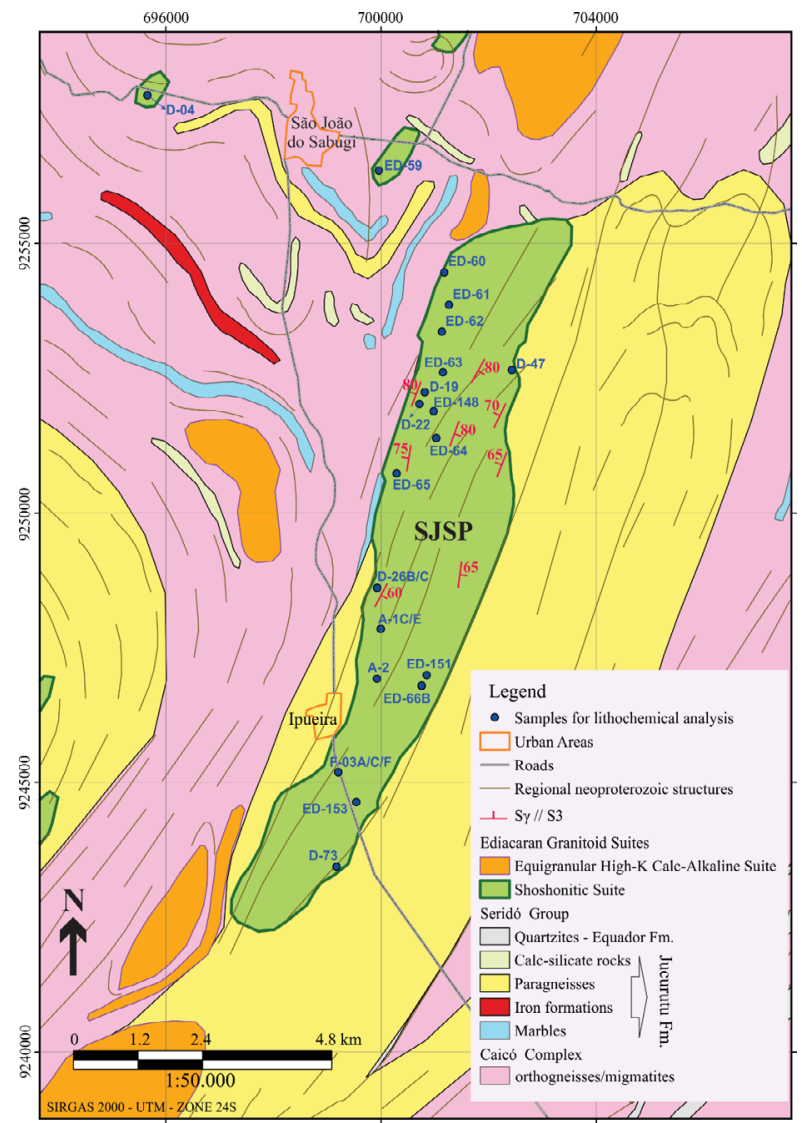

$S \gamma$ : magmatic foliation; $S_{3}$ : regional foliation associated with the $D_{3}$ Ediacaran deformation.

Figure 2.Localgeological setting oftheSãoJoãodoSabugiPluton(SJSP) and surrounding areas (Rio Piranhas-Seridó Domain, northeastern Borborema Province, NE Brazil) showing the location of the samples analyzed for whole rock chemistry. Modified and adapted from Costa et al. (2018).

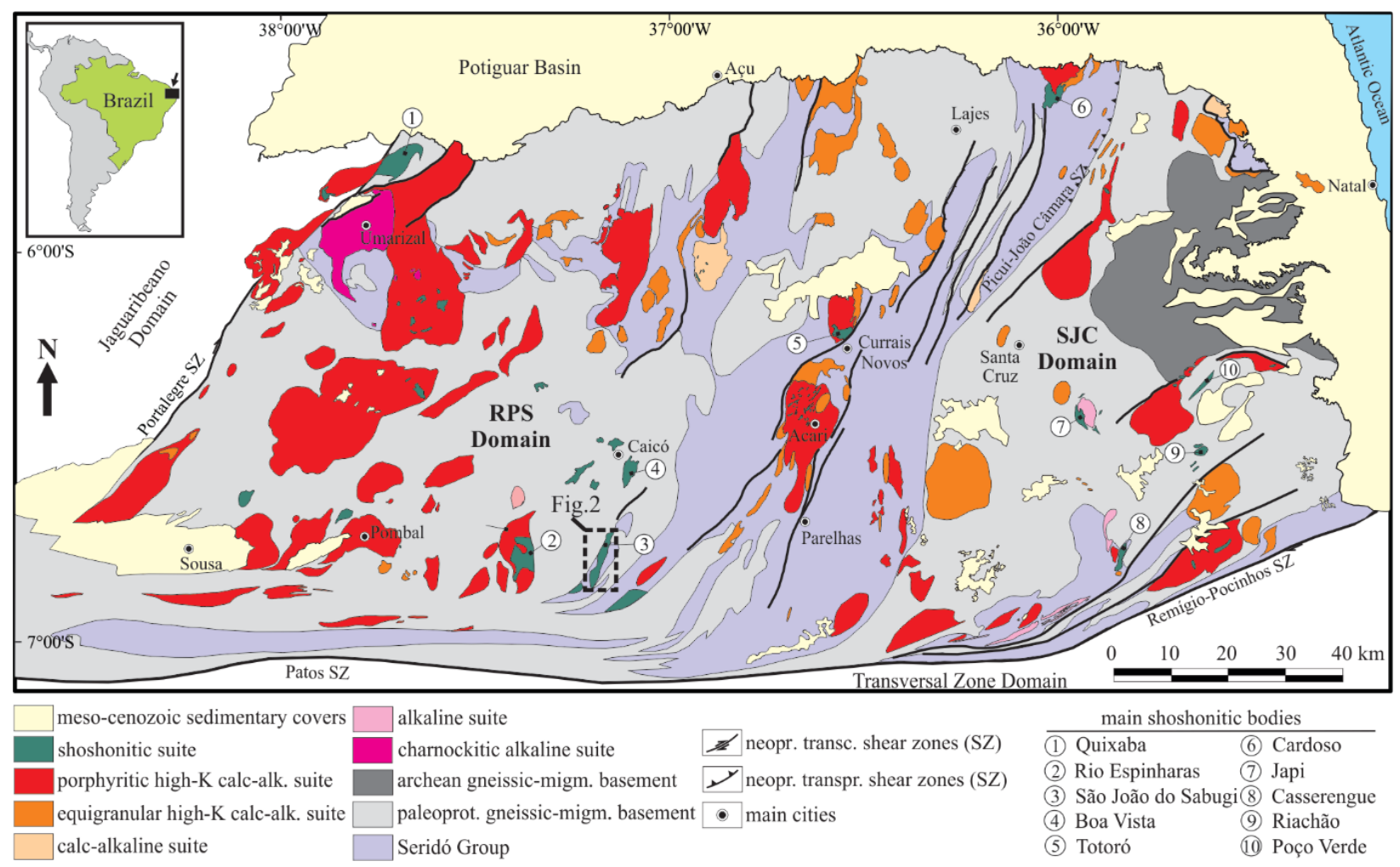

Source: modified from Nascimento et al. (2000, 2015).

Figure 1. Regional geological setting of the Rio Piranhas-Seridó and São José do Campestre Domains, northeastern Borborema Province (NE Brazil), showing the suites that encompasses the Ediacaran magmatism that have affected this region, with emphasis on the main bodies of the shoshonitic suite. Inset shows the location of Figure 2 that illustrates the study area. 
All these rocks are covered by late Neoproterozoic metasupracrustal rocks of the Seridó Group, which includes the Jucurutu on the bottom (paragneisses, marbles, calc-silicate rocks and iron formations), Equador on an intermediate level (quartzite and metaconglomerates) and Seridó on the top (mostly mica schists) formations (Jardim de Sá 1994, Van Schmus et al. 2003, Hollanda et al. 2015). The SJSP intrudes rocks of the Caicó Complex and the Jucurutu Formation (Fig. 2).

\section{MATERIALS AND METHODS}

This work presents, besides conventional field and petrographic data, whole rock and mineral chemical data for rocks of the SJSP.

\section{Whole rock chemistry}

Part of the lithochemical data for the SJSP reported in this work was compiled from Jardim de Sá (1994). This database includes major and trace element analyses for 18 representative samples. The data were obtained by inductively coupled plasma atomic emission spectrometry (ICP-AES) and inductively coupled plasma mass spectrometry (ICP-MS) at the Centre de Recherches Petrographiques et Géoquimiques (CRPG/ CNRS) in Nancy, France, following the analytical routines described in Govindaraju and Mevelle (1987). Nine additional samples (including samples from small satellite bodies to the west of the investigated pluton) were analyzed by X-ray fluorescence (XRF) and ICP-AES (major elements) and ICP-MS (trace elements) at ALS Brasil (samples D-22, D-26B, D-26C, D-47, D-73; analytical routines ME-MS81d available at https: / / www.alsglobal.com/\#services-section/services-detail) and SGS Geosol (samples D-04, D-19, D-22.1, D-25; analytical routines available at www.sgsgeosol.com.br) laboratories. The whole data set (27 samples) is available as Supplementary Table A1. In all cases, analytical uncertainties are better than $5 \%$ for most elements. Information on the quality control standards used are provided in the Supplementary Table A2.

\section{Mineral chemistry}

The composition of plagioclase, pyroxene, biotite, and amphibole of the main monzodiorite rock group (four representative samples) were obtained by in-situ chemical semiquantitative energy dispersive X-ray (EDX) microanalyses in a scanning electron microscope (SEM), model VEGA3 (TESCAN), coupled with an EDX microanalysis system model EDX-7000/8000 (Oxford Instruments) at the Laboratório de Caracterização de Minerais e Materiais (LACAMM), Instituto Federal de Educação, Ciência e Tecnologia do Rio Grande do Norte (IFRN). The analytical conditions were $20 \mathrm{kV}$ for column acceleration voltage, $20 \mathrm{nA}$ and $1 \mu \mathrm{m}$ for beam current and diameter, respectively, and $\sim 50$ s of acquisition time. The quantified spectral lines, standards and associated uncertainties $(2 \sigma)$ were: $\mathrm{SiK} \alpha$ (quartz, \pm 0.4 ), TiK $\alpha$ (metallic titanium, \pm 0.2 ), $\mathrm{AlK} \alpha$ (corundum, \pm 0.2 ), Fe $\mathrm{K} \alpha$ (metallic iron, \pm 0.4 ), $\mathrm{MgK} \alpha$ (periclase, \pm 0.3 ), $\mathrm{MnK} \alpha$ (metallic manganese, \pm 0.2 ), $\mathrm{CaK} \alpha$ (wollastonite, \pm 0.2 ), $\mathrm{NaK} \alpha$ (amelia albite, \pm 0.2 ), and $\mathrm{KK} \alpha$ (MAD-10 feldspar, \pm 0.2 ). The $\mathrm{H}_{2} \mathrm{O}$ contents in biotite and amphibole were estimated following Tindle and Webb (1990).
Amphibole structural formula and $\mathrm{Fe}^{2+} / \mathrm{Fe}^{3+}$ ratio were calculated to 13 total cations excluding $\mathrm{Ca}, \mathrm{Na}$ and $\mathrm{K}$ (13eCNK), with nomenclature according to Leake et al. (1997). Cation proportions for pyroxene, biotite and plagioclase were computed based on 6, 22 and 8 oxygens, respectively (Deer et al.2013).

\section{RESULTS}

\section{Field aspects and petrography}

The SJSP is composed mainly of gabbros/diorites, monzodiorites, quartz monzodiorites, and granodiorites, and minor aplitic and pegmatitic dykes. It does not exhibit a lithological zoning and, in fact, such compositional variation can be observed in the outcrop scale, which makes a faciological mapping difficult. On textural grounds, the mafic rocks are usually massive, whereas the felsic ones show magmatic structures and plastic shear zones. These latter features are associated with the regional $\mathrm{D}_{3}$ Ediacaran deformation, which is marked by oriented mafic minerals in a foliation trending NE-SW (Fig. 2). The studied rocks are coarse-grained, porphyritic, leuco- to melanocratic, and define three rock groups (Fig. 3) namely:

- gabbro-diorite (include the more mafic types);

- monzodiorite;

- granodiorite encompassing the felsic types.

Their main petrographic and mineralogical aspects are described below. Further details are given in Table 1.

Gabbro-diorites (Fig. 3A) are less exposed on the surface, which makes sampling difficult. These rocks appear as small satellite bodies to the west of the SJSP main body (Fig. 2), as well as in few outcrops in the northern portion, where they frequently appear as interdigitations or in gradual contacts with monzodiorite (Figs. 4A and 4B). They include massive, inequigranular, meso- to melanocratic (color index (CI) 60-80; Fig. 3A) gabbro, gabbronorite and diorite, eventually with cumulus textures. The mafic phases comprise clinopyroxene (augite) \pm orthopyroxene (hypersthene) + hornblende \pm biotite (Fig. 5A, Tab. 1). Plagioclase $\left(\mathrm{An}_{45-63}\right.$ by the Michel-Lévy method) is the main felsic mineral, with rare quartz and perthitic orthoclase. Accessories are titanite, euhedral magmatic epidote, and magnetite, as well as minute apatite and zircon grains.

The monzodiorite rock group includes the most common lithotypes in the SJSP. These are spatially distributed across the pluton and comprise porphyritic, leuco- to mesocratic (CI 20-50) monzodiorites, quartz monzodiorites, and minor monzonites (Figs. 3B and 3C). Hornblende \pm biotite are the main mafic minerals, but augite \pm hypersthene (as preserved cores within augite) also occur in the most mafic types. These rocks have massive or foliated structures, the latter defined by preferred orientation of hornblende and biotite crystals (Fig. 5B), and concentrically zoned plagioclase megacrysts $\left(\mathrm{An}_{24-36}\right.$ from mineral chemistry) (Fig. 5C). A late-crystallizing second generation of biotite and minor acicular actinolite and/or grunerite replace hornblende rims and cleavage planes (Fig. 4D). The most relevant accessory phases are titanite (three generations), opaque minerals (magnetite/titanomagnetite; 
two generations), epidote (two generations), allanite, apatite and zircon (Tab. 1). The first generation (main to late-magmatic) of magnetite, titanite and epidote appears as isolated euhedral grains or as coronas on allanite (epidote). The second generation corresponds to anhedral post-magmatic grains replacing pyroxenes (magnetite), and amphiboles and biotite along crystal rims and cleavage planes.

The granodiorite rock group (Figs. 3D) occurs as intercalations, apophysis and/or segregations within monzodiorite (Figs. 4C and 4D). The main lithotypes are foliated, inequigranular to porphyritic, leucocratic (CI $\sim 10-20)$ granodiorite and quartz monzonite. Foliation is defined by the preferred orientation of biotite (Figs. 3D and 5G), which is the chief mafic mineral along with scarce hornblende (Tab. 1). Plagioclase $\left(\mathrm{An}_{\sim 25}\right.$ by the Michel-Lévy method), as well as orthoclase and/or microcline occur as megacrysts (Fig. $5 \mathrm{H}$ ). Myrmekites are common, and the accessory minerals are titanite, magnetite, zircon, apatite, allanite, and epidote (Tab. 1). As in monzodiorites, magnetite, titanite and epidote appear in two textural generations in the granodiorites: the first is magmatic and crystallized as euhedral grains or as coronas on titanomagnetite (titanite) and allanite (epidote). The second generation is post-magmatic, formed after amphibole and biotite.

\section{Petrographic evidences of open-system processes}

Evidences of open-system magmatic processes are widespread in the SJSP, especially among the monzodiorites and granodiorites. These include microgranular enclaves, schlierens and digestion of metasedimentary xenoliths (Tab. 1). Centimetric to decametric mafic-intermediate microgranular enclaves with ellipsoidal, sigmoidal, or globular shapes, as well as schlierens (Figs. 4E and 4F) are arranged parallel to the main foliation. Hornblende and biotite are the mafic phases (pyroxene is rare), whereas plagioclase xenocrysts from the host rocks are occasional. Such observations suggest local occurrence of mechanical magma mixing and/or mingling processes.

Xenoliths of the Seridó Group are relatively common in monzodiorites (Fig. 4G). These include garnet-biotite schists, paragneisses and calc-silicate rocks. The xenoliths are rounded, globular, ellipsoidal, and irregularly-shaped, and show reaction rims with the host rocks marked by intense epidotization. Some of them are aligned parallel to the main NNE-SSW foliation. Schist and paragneiss xenoliths show local evidence of partial melting (digestion) and the crystallization of garnet crystals close to the contact with the monzodiorites (Fig. $4 \mathrm{H}$ ). Moreover, samples of monzodiorites and granodiorites collected near calc-silicate xenoliths frequently show interstitial
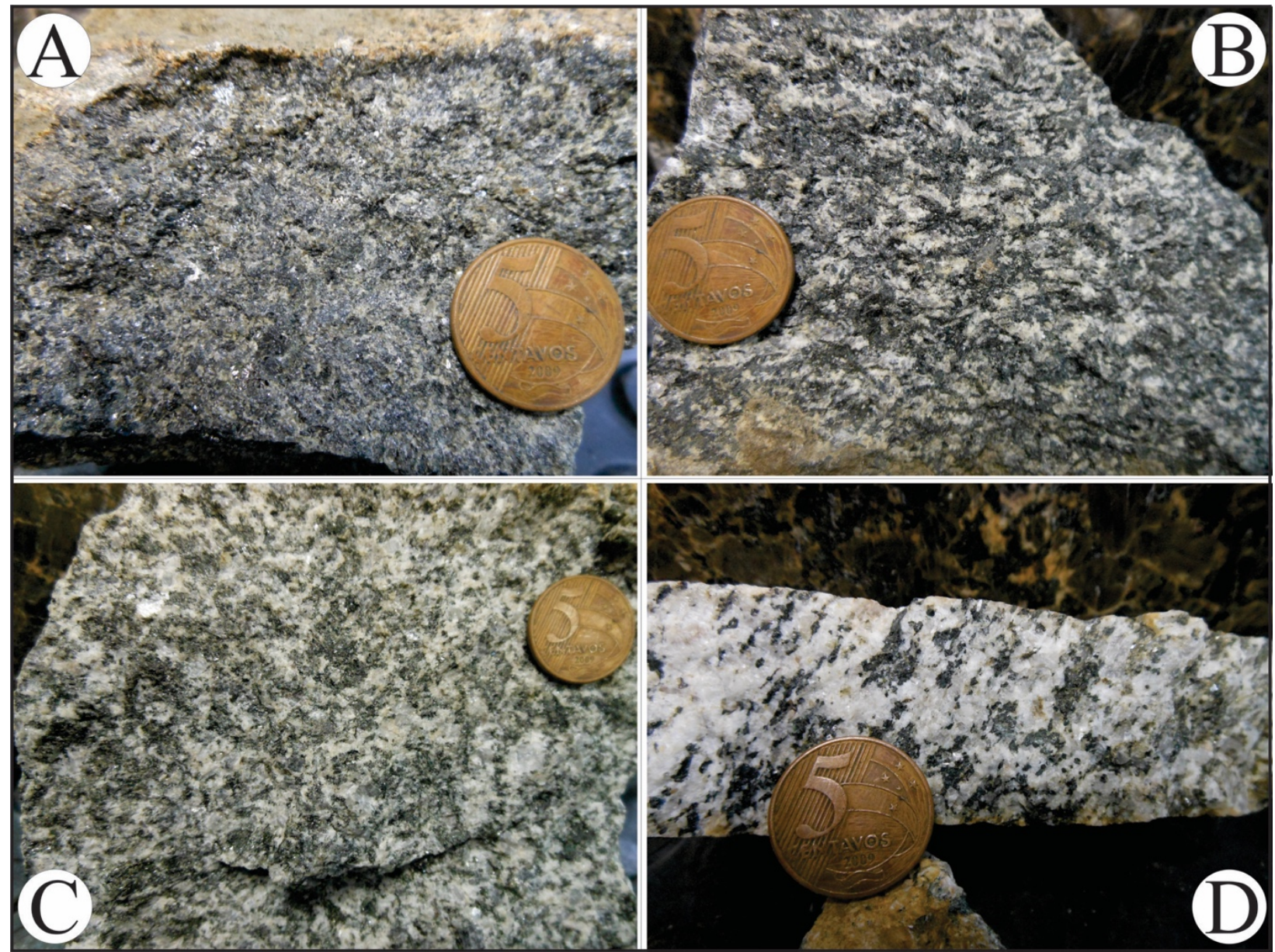

Figure 3. Typical macroscopic aspects of the rocks forming the São João do Sabugi rocks. (A) Massive melanocratic gabbro-diorite (color index (CI) 65\%). Mafic minerals include pyroxenes and amphiboles. (B and C) Massive monzodiorites, including more mafic (in B; CI $\sim 50 \%$ ) and more felsic (in C; CI $\sim 35 \%$ ) varieties. Amphibole \pm biotite ( \pm pyroxenes) are the main mafic minerals (black portions). (D) Foliated leucocratic (CI 10\%) granodiorite near the NW outer part of the pluton. Note preferred orientation $\left(S \gamma / / S_{3}\right)$ of biotite (black) and feldspar (white). Coin diameter $=2 \mathrm{~cm}$. 
calcite in apparent equilibrium with the magmatic mineral assemblage (Fig. 5I; Tab. 1).

\section{Whole rock geochemistry}

We present an overview of the main geochemical characteristics of the SJSP. These are compared with other occurrences of the shoshonitic suite in the RPS and SJC domains, according to integrations of Campos et al. (2002), Hollanda et al. (2003), Nascimento et al. (2000, 2015), Macedo Filho and Souza (2016), Guimarães et al. (2017), and references therein. Due to the sampling difficulties mentioned above, the analyzed gabbro-diorite samples are from petrographically similar small satellite bodies nearby the SJSP main body (Fig. 2).

The SJSP rocks are plotted in the total alkali-silica (TAS) diagram (Middlemost 1994) along with data of the shoshonitic suite for comparison purposes (Fig. 6). The SJSP shows $\mathrm{SiO}_{2}$ ranging from 48.3 to $65.3 \mathrm{wt} . \%$, and relatively high total alkali $\left(\mathrm{Na}_{2} \mathrm{O}+\mathrm{K}_{2} \mathrm{O}\right)$ contents $(2.1-8.2 \%$; Suppl. Tab. A1), although relatively lower than those recorded in the shoshonitic suite (up to $10.8 \%$ ). Therefore, SJSP rocks classify as gabbros (gabbro-diorite group), monzodiorites to monzonites (monzodiorite group) and quartz monzonites to granodiorites (granodiorite group). Furthermore, the high alkali contents, especially $\mathrm{K}_{2} \mathrm{O}(2.2-5.4 \mathrm{wt} . \%)$, confirm the alkali-calcic and shoshonitic affinities in the diagrams of Figures $7 \mathrm{~A}$ and $7 \mathrm{~B}$ for most of the analyzed samples, except for the gabbros which show calc-alkaline signatures, as also reported for similar, less evolved, occurrences within the shoshonitic suite.

The studied rocks are metaluminous (normative diopside up to $10.7 \mathrm{wt} . \%$ ) to slightly peraluminous (normative corundum $<0.7$ wt.\%) with $\mathrm{Al}_{2} \mathrm{O}_{3}$ contents varying from 14.4 to $17.3 \%$, and molar $\mathrm{A} / \mathrm{NK}\left(\mathrm{Al}_{2} \mathrm{O}_{3} / \mathrm{Na}_{2} \mathrm{O}+\mathrm{K}_{2} \mathrm{O}\right)$ and $\mathrm{A} / \mathrm{CNK}$ $\left(\mathrm{Al}_{2} \mathrm{O}_{3} /\left(\mathrm{CaO}+\mathrm{Na}_{2} \mathrm{O}+\mathrm{K}_{2} \mathrm{O}\right)\right.$ indexes between 1.4-2.6 and 0.4-1.0, respectively, as observed for other occurrences of the shoshonitic suite (Fig. 7C). $\mathrm{MgO}$ and FeOt contents are in the ranges of 1.3-11.9 wt.\% and 4.3-13.2 wt.\%, respectively, yielding values for the $m g \#$ parameter $\left(\mathrm{mol} \mathrm{MgO}^{*} 100 /(\mathrm{MgO}\right.$ $+\mathrm{FeO})$ ) between 26 and 71 . The enclaves register the highest

Table 1. Summary of the field and petrographic characteristics of the rock groups forming the São João do Sabugi Pluton, along with some key geochemical indexes.

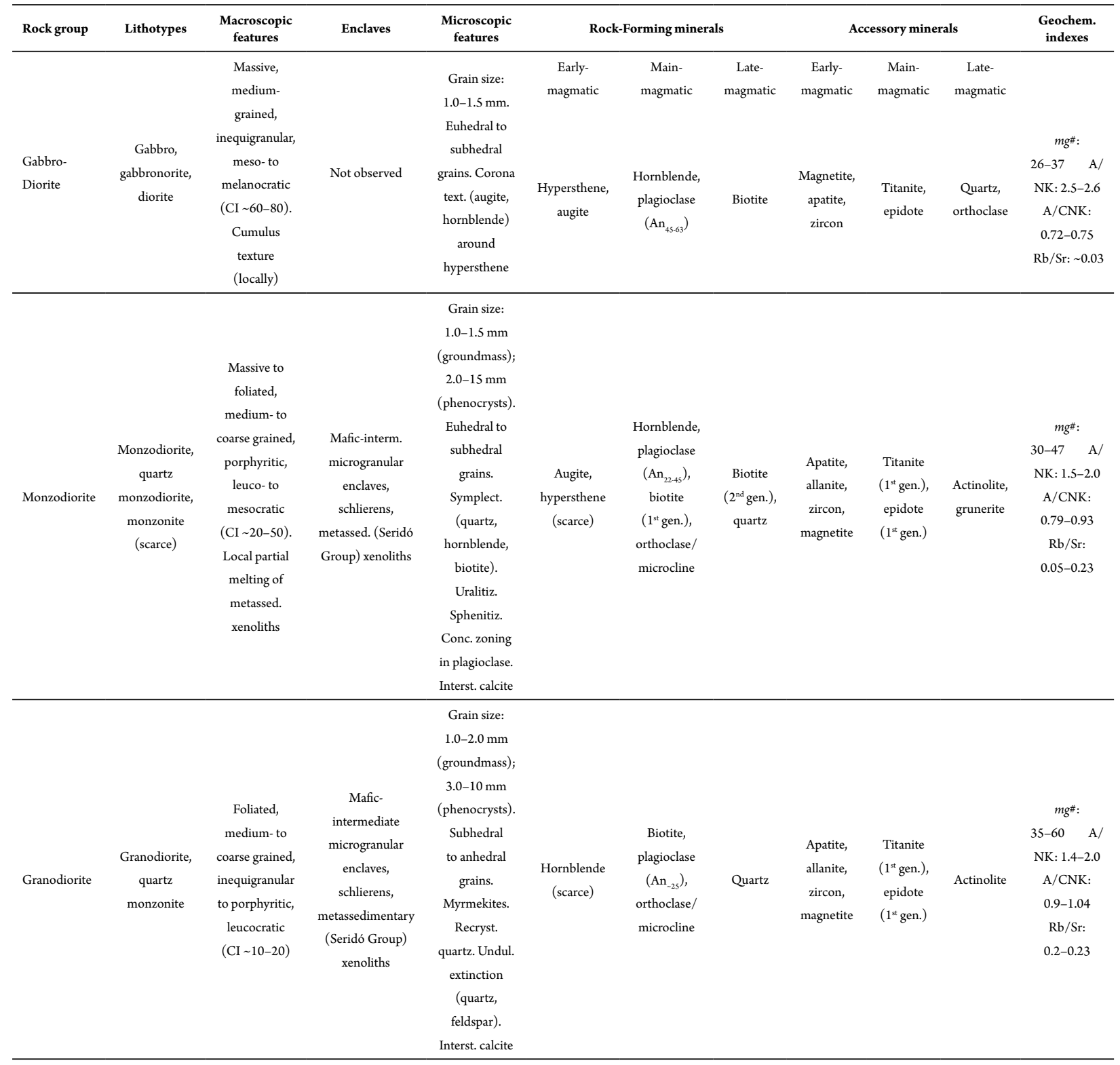




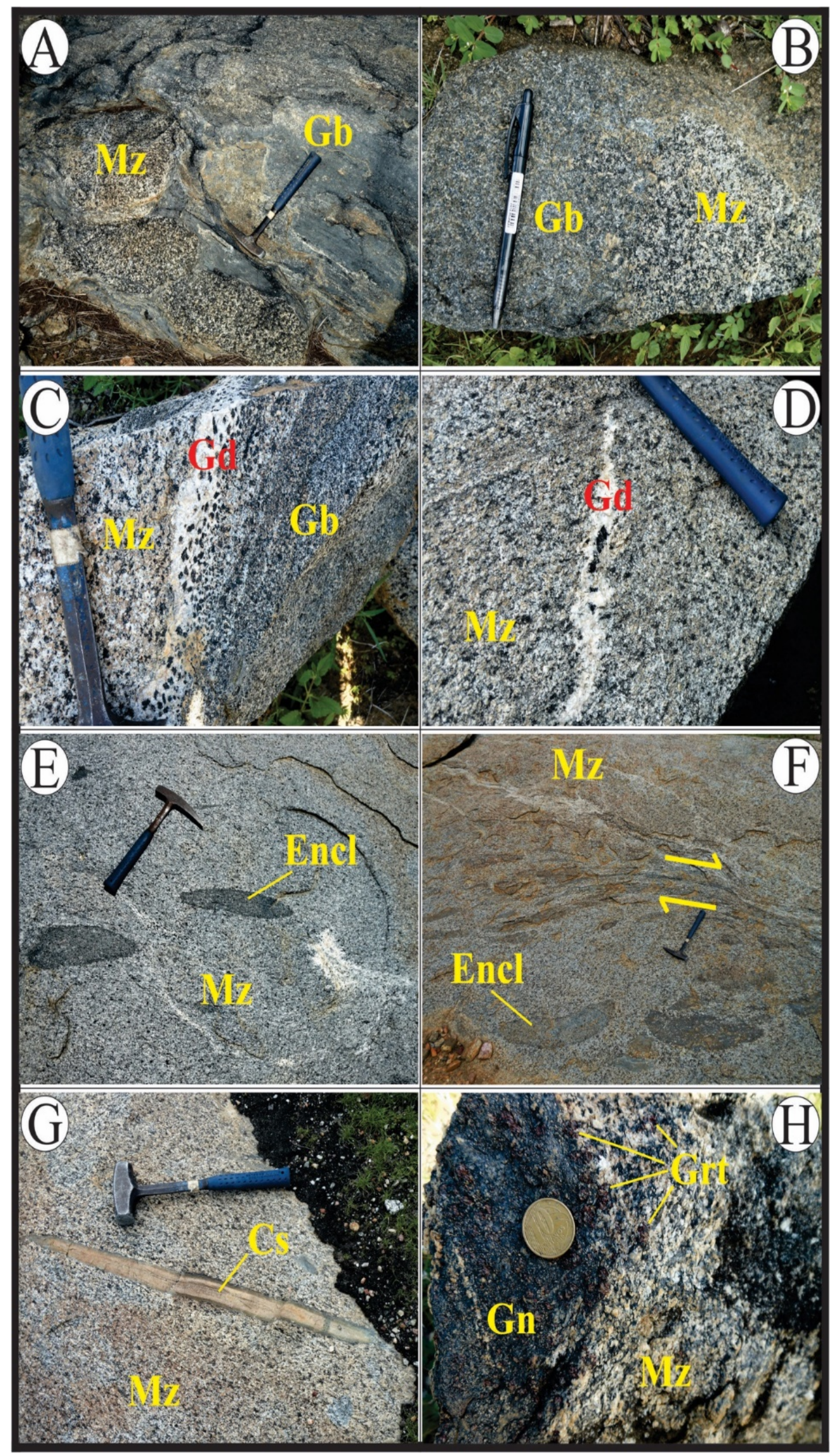

Figure 4. Macroscopic structures of the São João do Sabugi rocks. (A) Intercalation between gabbro-diorite (Gb) and monzodiorite (Mz). (B) Gradual contact between gabbro-diorite $(\mathrm{Gb})$ and monzodiorite $(\mathrm{Mz})$. (C) Contact zone between gabbro-diorite (Gb) and monzodiorite $(\mathrm{Mz})$. Note felsic segregation characterizing the granodioritic rocks (Gd), with millimetric crystals of amphibole and biotite (dark crystals). (D) Granodiorite (Gd) liquid filling a late-magmatic sinistral extensional zone trending N45 $\mathrm{Az}$ in monzodiorite (Mz). (E and F) Maficintermediate, microgranular, centimetric to decametric elliptical enclaves (Encl) that outline a ductile dextral shear zone of ENE-WSW direction. (G) Calc-silicate rock xenoliths (Cs) with reaction rims marked by intense epidote formation (greenish border). (H) Garnet concentration $(\mathrm{Grt})$ in the contact zone between paragneiss xenoliths $(\mathrm{Gn})$ and monzodiorite $(\mathrm{Mz})$. Hammer length $=33 \mathrm{~cm}$; pen length $=$ $14 \mathrm{~cm}$; coin diameter $=2 \mathrm{~cm}$. Hammer handle points to north in D, E, F and G. 
$\mathrm{MgO}$ abundances, whereas the gabbros are Fe-enriched rocks. In fact, $\mathrm{FeOt}$ abundances for the SJSP rocks are relatively lower when compared to other shoshonitic occurrences. This can be seen in the diagram of Figure 7D, in which the SJSP is essentially magnesian, a typical signature of $\operatorname{arc}$ magmas (e.g., Frost et al. 2001)

Samples from all SJSP facies define roughly continuous trends in Harker-type variation diagrams (Fig. 8; Suppl. $\mathrm{Tab} . \mathrm{A1}$ ). There are negative correlations of $\mathrm{FeOt}, \mathrm{MgO}, \mathrm{CaO}$ and $\mathrm{TiO}_{2}$, and positive with $\mathrm{K}_{2} \mathrm{O}$ against $\mathrm{SiO}_{2} . \mathrm{P}_{2} \mathrm{O}_{5}$ shows incompatible behavior in the less evolved varieties, becoming compatible when $\mathrm{SiO}_{2}$ are higher than 54-55 wt.\%, which indicates apatite saturation only in intermediate to acidic compositions. Trace elements $\mathrm{Sr}, \mathrm{Ni}$ and V show negative correlations, whereas $\mathrm{Ba}, \mathrm{Rb}$ and $\mathrm{Zr}$ are incompatible elements. These signatures are indicative of fractional crystallization processes during the evolution of the SJSP magmas.

Figure 9 depicts chondrite-normalized trace element spidergrams and rare-earth elements (REE) patterns. The SJSP rocks exhibit relative enrichment in large ion lithophile elements
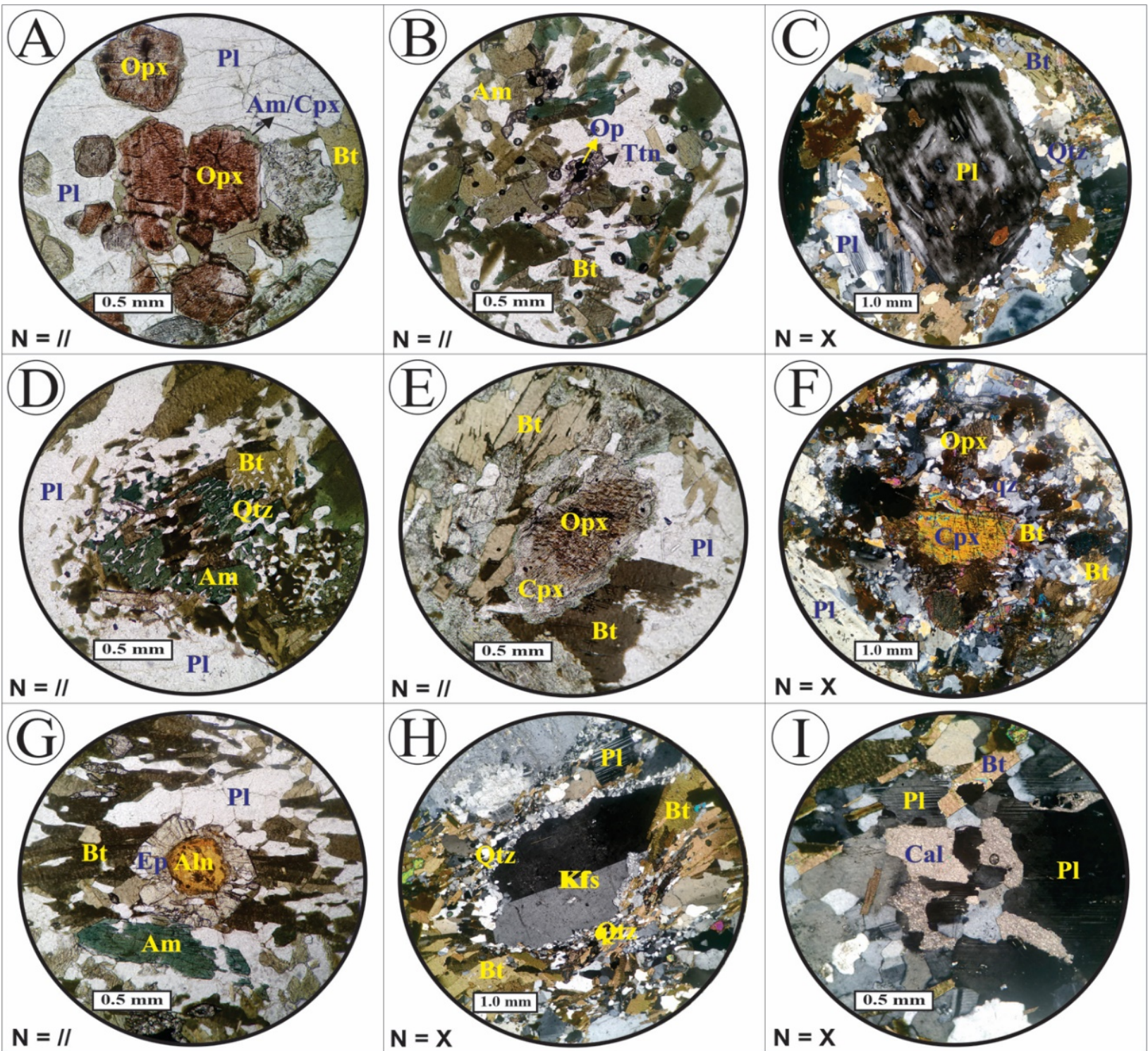

Opx: orthopyroxene; Cpx: clinopyroxene; Pl: plagioclase; Am: amphibole; Bt: biotite; Op: opaque minerals; Ttn: titanite; Qtz: quartz; Kfs: potassic feldspar; Aln: allanite; Ep: epidote; Cal: calcite.

Figure 5. Microscopic aspects of the São João do Sabugi rocks. (A) Corona of amphibole and/or clinopyroxene (augite/hedenbergite) around orthopyroxene (hypersthene), along with plagioclase (labradorite) in gabbro-diorite. The pyroxenes are partially replaced by opaque minerals (magnetite). (B) Amphibole (hornblende) in contact and/or replaced by biotite, along with plagioclase \pm interstitial quartz (clear minerals) in monzodiorite. Note sphenitization around opaque minerals (mainly titanomagnetite of first generation). (C) Plagioclase showing concentric zoning surrounded by biotite in quartz-monzodiorite. (D) Symplectitic intergrowth of quartz, amphibole (hornblende) and biotite in quartzmonzodiorite showing evidence of re-equilibration of high-T magmatic early formed phase. (E) Destabilization of orthopyroxene (hypersthene) for clinopyroxene (augite), which in turn is replaced by biotite in monzodiorite. Eventually, colorless actinolite and grunerite crystals occur close to clinopyroxene rims (not visible). Orthopyroxene is also partially altered to magnetite of second generation. (F) Euhedral clinopyroxene (augite) surrounded by biotite and plagioclase in the monzodioritic facies; note small crystal of brown orthopyroxene and opaque minerals (magnetite/ titanomagnetite of first generation). (G) Euhedral to subhedral allanite mantled by magmatic epidote (first generation) in the granodioritic facies. Note preferred orientation of biotite plates. $(\mathrm{H})$ Potassic feldspar (orthoclase) with Carlsbad twinning surrounded by quartz grains and biotite in the granodioritic facies. (I) Interstitial calcite in apparent equilibrium with plagioclase, quartz, and biotite in the monzodioritic facies. Photomicrographs under transmitted light with uncrossed $(\mathrm{N}=/ /)$ and crossed $(\mathrm{N}=\mathrm{X})$ polarizers. 


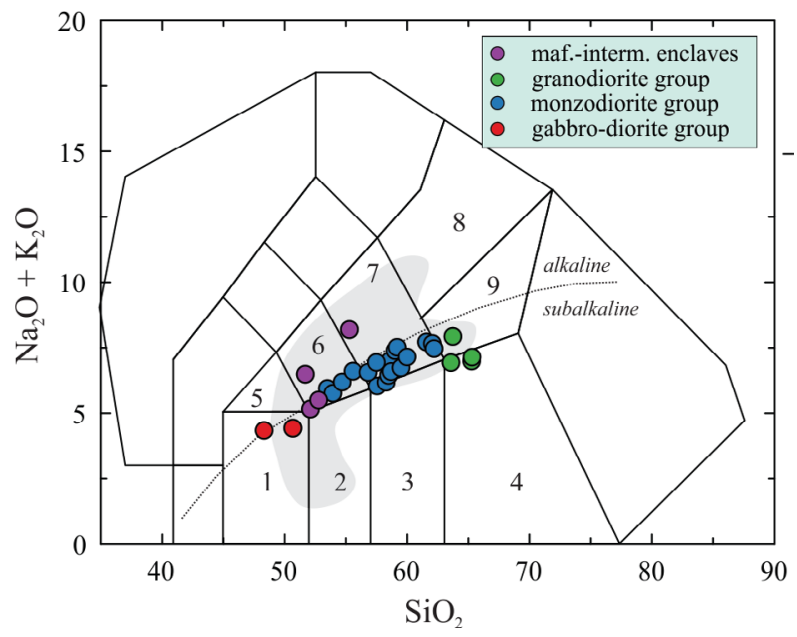

Figure 6. Total alkalis vs. $\mathrm{SiO}_{2}$ (in wt.\%) diagram (field limits from Middlemost 1994) for the São João do Sabugi rocks. The boundary between the alkaline and subalkaline series is after Irvine and Baragar (1971). Fields are: (1) gabbro; (2) diorite gabbro; (3) diorite; (4) granodiorite; (5) monzogabbro; (6) monzodiorite; (7) monzonite; (8) syenite; (9) quartz monzonite. Gray field: compositional range of the Shoshonite Suite in the Rio Piranhas-Seridó and São José do Campestre Domains for comparison purposes (data compiled from Campos et al. 2002, Nascimento et al. 2000, 2015, Macedo Filho and Souza 2016, Guimarães et al. 2017 and references therein).
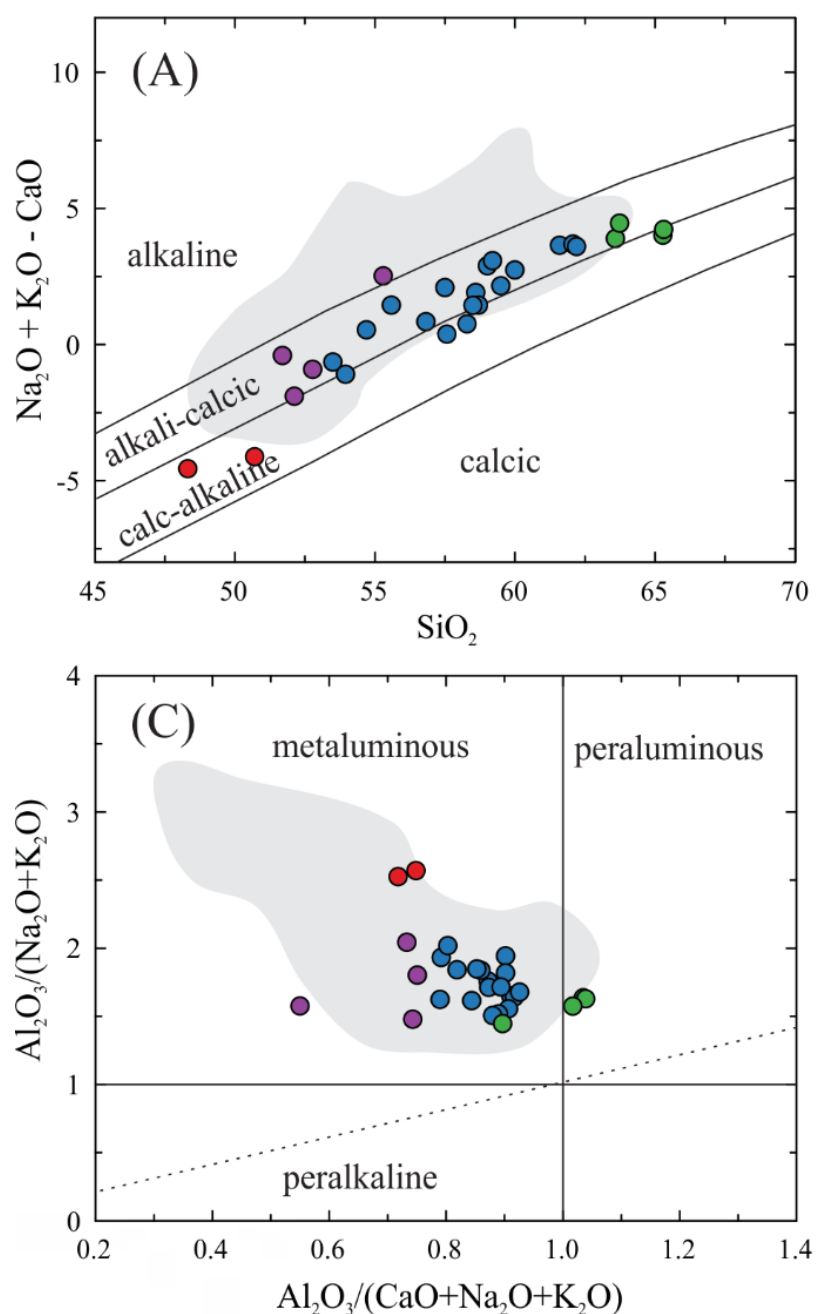

(LILE; especially $\mathrm{Ba}, \mathrm{Rb}$, Th and $\mathrm{K}$ ) relative to high field strength elements (HFSE), from the less to the more evolved varieties and enclaves (see also Suppl. Tab. A1). They also show negative $\mathrm{Nb}$-Ta anomalies (monzodiorites), although less pronounced than those for other Ediacaran shoshonitic bodies in the RPS and SJC Domains. Of note, the same pattern is registered in Archean and Paleoproterozoic mafic and intermediate rocks within these domains (Souza et al. 2007, 2016). The $\mathrm{Rb} / \mathrm{Sr}(0.03-0.28)$ and $\mathrm{Th} / \mathrm{U}(3.5-6.9)$ ratios are close to the values of Rudnick and Gao (2003) for the lower $(\mathrm{Rb} / \mathrm{Sr}=0.03 ; \mathrm{Th} / \mathrm{U}=6)$, upper $(\mathrm{Rb} / \mathrm{Sr}=0.26 ; \mathrm{Th} / \mathrm{U}=3.9)$ and bulk continental crust $(\mathrm{Rb} / \mathrm{Sr}=0.15 ; \mathrm{Th} / \mathrm{U}=4.3)$, suggesting involvement of crustal components in the SJSP magma evolution. Furthermore, these signatures are akin to those registered for shoshonitic arc magmas (Morrison 1980, Pearce 1982, Bonadiman et al. 1994, Hollanda et al. 2003, Nardi 2016).

Primitive mantle-normalized REE patterns reveal relative light REE enrichment over heavy REE $\left(9.9<\mathrm{La}_{\mathrm{N}} / \mathrm{Yb}_{\mathrm{N}}<31\right)$, as well as discrete negative Eu anomalies, with $\mathrm{Eu} / \mathrm{Eu}^{*}[=\mathrm{EuN} /$ $(\mathrm{SmN}+\mathrm{GdN}) / 2$ ], mainly between 0.7 and 1.2.

Contrasts in the SJSP trace and REE patterns can be due to fractional crystallization processes (e.g. plagioclase, hornblende, titanite, apatite) or distinct redox conditions (positive
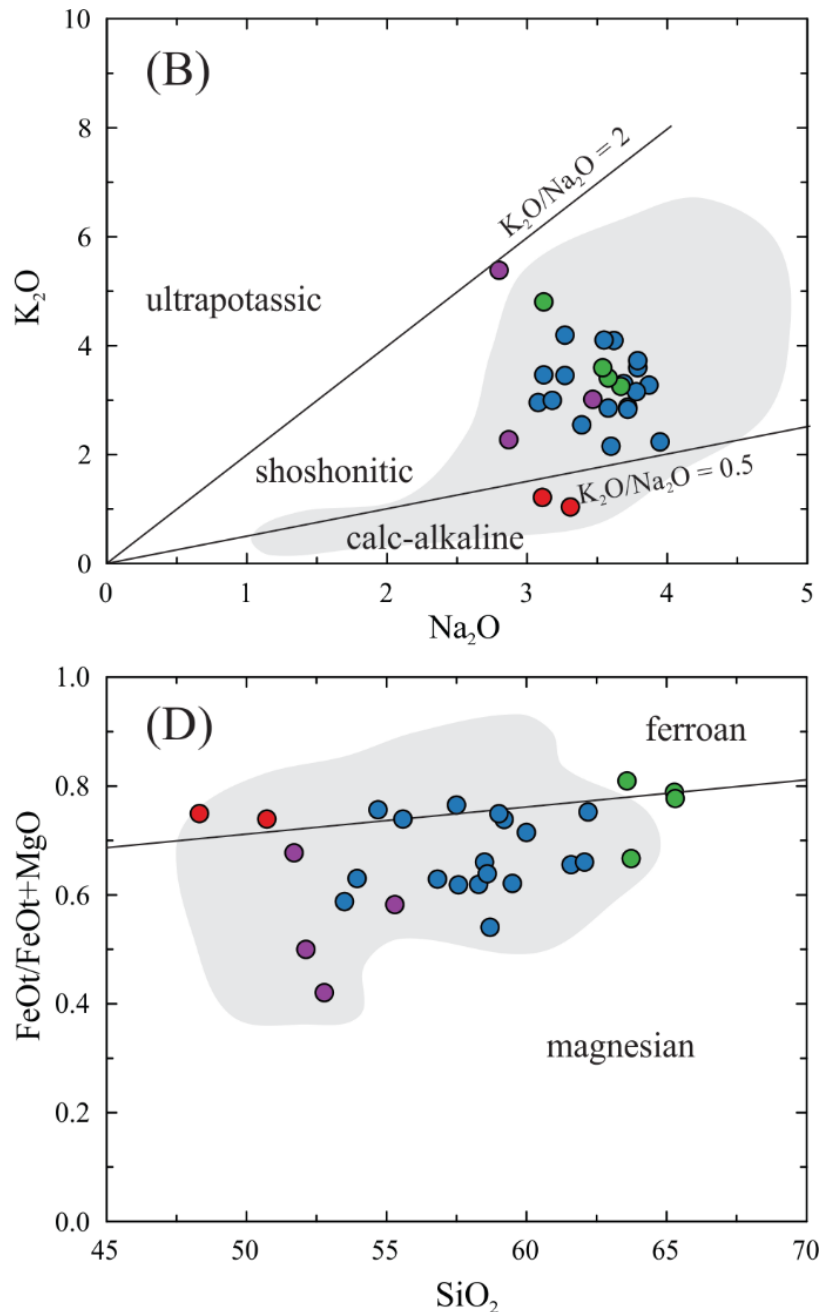

Figure 7. Lithochemical binary diagrams for the São João do Sabugi rocks. (A) $\mathrm{SiO}_{2}$ vs. $\mathrm{Na}_{2} \mathrm{O}+\mathrm{K}_{2} \mathrm{O}-\mathrm{CaO}$ (wt. \%) diagram (MALI index) by Frost et al. (2001). (B) $\mathrm{Na}_{2} \mathrm{O}$ vs. $\mathrm{K}_{2} \mathrm{O}$ (wt. \%) classification diagram after Foley et al. (1987), modified from Middlemost (1975). (C) A/ $\mathrm{CNK}\left(\mathrm{Al}_{2} \mathrm{O}_{3} / \mathrm{CaO}+\mathrm{Na}_{2} \mathrm{O}+\mathrm{K}_{2} \mathrm{O}\right)$ vs. A $/ \mathrm{NK}\left(\mathrm{Al}_{2} \mathrm{O}_{3} /\left(\mathrm{Na}_{2} \mathrm{O}+\mathrm{K}_{2} \mathrm{O}\right)\right.$ molar diagram of Shand (1943). (D) $\mathrm{SiO}_{2}$ vs. fe\# ratio $(\mathrm{FeOt} / \mathrm{FeOt}+$ $\mathrm{MgO}$ ) (wt. \%) diagram of Frost et al. (2001). Gray field: compositional range of the shoshonite suite in the Rio Piranhas-Seridó and São José do Campestre Domains (references as in Figure 6), for comparison purposes. Symbols as in Figure 6. 
and negative Eu anomalies) during crystallization (e.g., Hoskin et al. 2000, Shearer et al. 2006, Philpotts and Ague 2009, Burnham et al. 2015).

\section{Mineral chemistry}

Table 2 lists representative compositions of plagioclase, clinopyroxene, amphibole and biotite crystals from the monzodiorites of the SJSP. The data set is illustrated in Figure 10.

Plagioclase corresponds to oligoclase and andesine, with compositions in the range $\mathrm{An}_{36-24}$ (Fig. 10A). Overall, the anorthite molecule contents decrease towards the rims of concentrically zoned crystals. Clinopyroxene crystals are commonly replaced by amphibole and correspond to augite, with compositions varying in the range $\mathrm{Wo}_{24-38} \mathrm{En}_{46-57} \mathrm{Fs}_{16-19}$ (Fig. 10B). Magnesium contents are higher than $\mathrm{Fe}^{2+}$, resulting in $m g \#[=\mathrm{Mg} /$ $(\mathrm{Mg}+\mathrm{Fe})]$ values around 0.74-0.77 (Tab. 2). Amphiboles have $m g \#$ values between 0.46 and 0.80 , Si between 6.746 and 7.754 cations per formula unit (cpfu), and classify mainly as ferro- and magnesio-hornblende. One analyzed acicular, light-green colored crystal that occur replacing hornblende registers the highest $m g^{\#}$ value, and it is classified as actinolite (Tab. 2; Fig. 10C). Al contents are between 0.952 and 2.103 $\mathrm{cpfu}$, and the sum $(\mathrm{Na}+\mathrm{K})_{\mathrm{A}}$ reaches a maximum of $0.296 \mathrm{cpfu}$ (Tab.2). Despite the fewness of available data, such compositional variations can be partially described by the Tschermak $\left(\mathrm{Al}_{2} \mathrm{Mg}_{-1} \mathrm{Si}_{-1}\right)$ and edenitic (NaAlSi ${ }_{-1}[]_{-1}$, where []$=$ vacancy) exchange vectors. Biotite does not have significant core-to-rim compositional zoning. However, there are compositional variations between isolated crystals and those replacing amphibole. Whereas the former is a $\mathrm{Mg}$-richer variety, with $m g \#$ values in the range $0.48-0.65(\mathrm{Fe} / \mathrm{Fe}+\mathrm{Mg}=0.35-0.52)$, and $\mathrm{Al}_{\text {total }}$ around $2.345-2.612 \mathrm{cpfu}$, the latter is slightly Fe-richer, with $m g \#$ values between 0.44 and $0.51(\mathrm{Fe} /(\mathrm{Fe}+\mathrm{Mg})=0.49-$ 0.56 ), and $\mathrm{Al}_{\text {total }}$ ranging from 2.72 to $2.817 \mathrm{cpfu}$ (Fig. 10D).

\section{Estimates of intensive crystallization parameters}

\section{Pressure}

The emplacement pressure for the SJSP were estimated with the Al-in-hornblende geobarometer calibration of
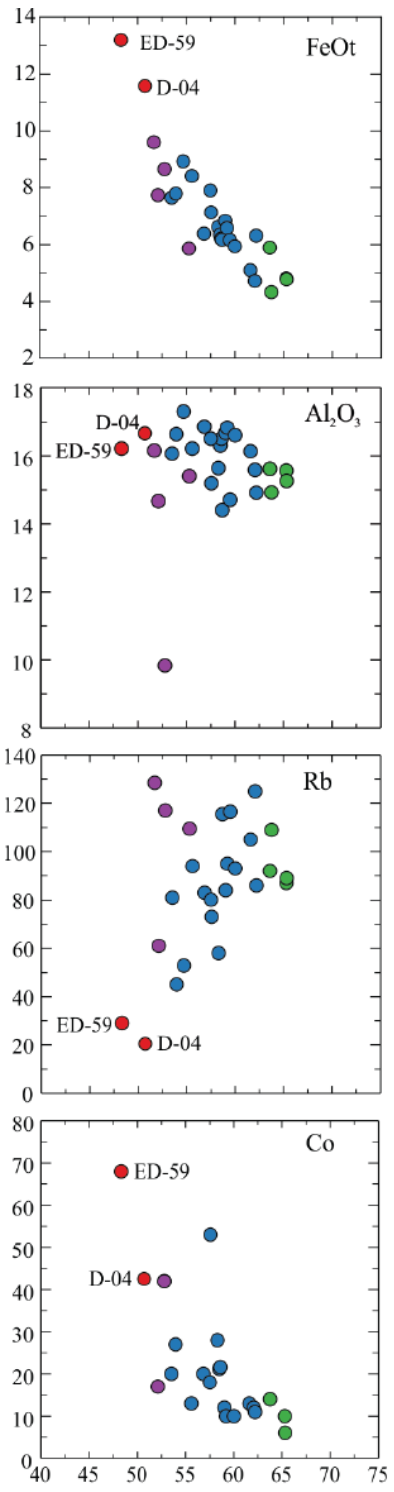

$\mathrm{SiO}$
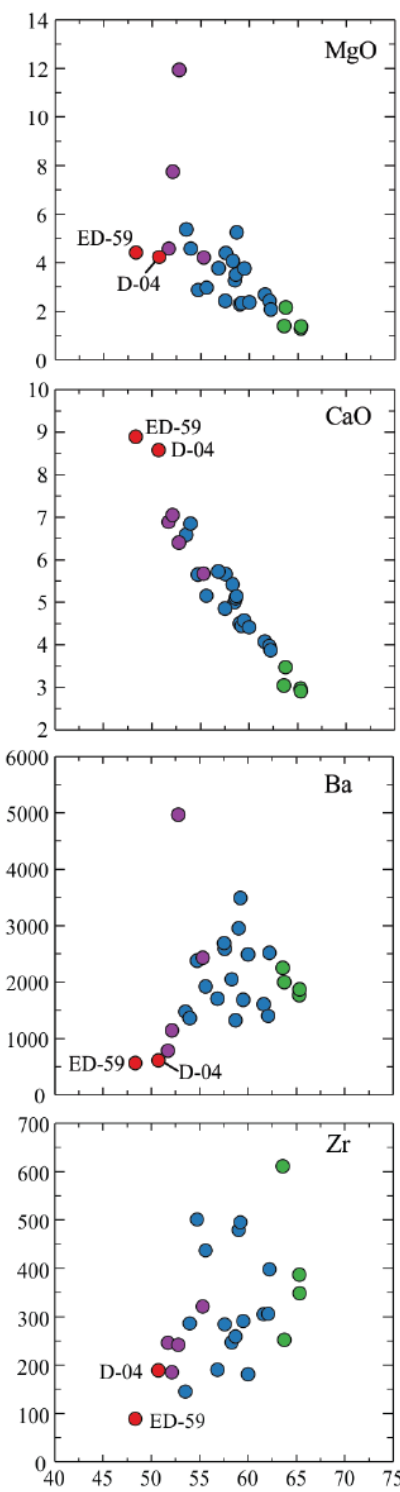

$\mathrm{SiO}_{2}$
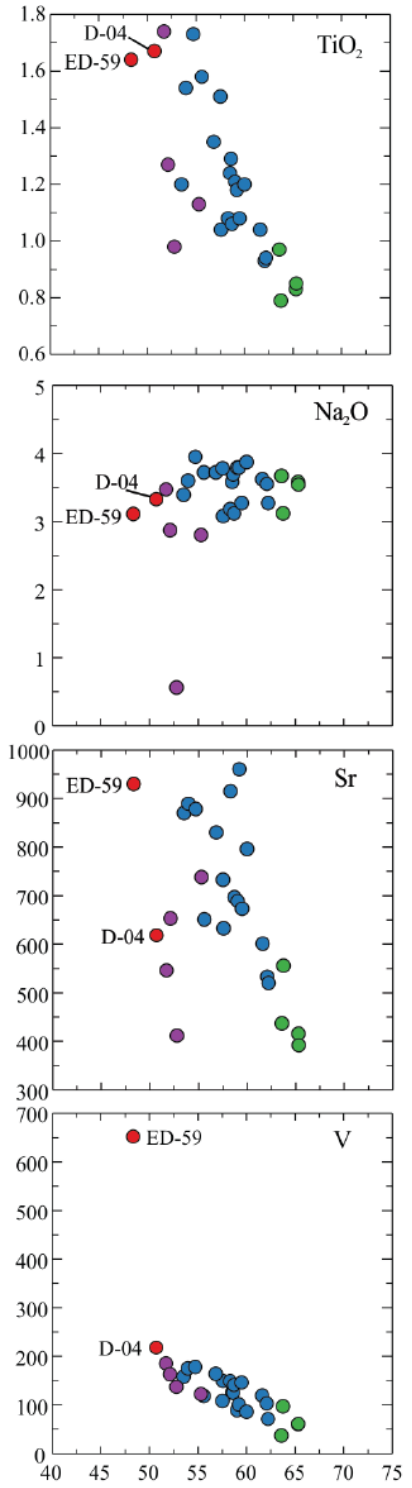

$\mathrm{SiO}_{2}$
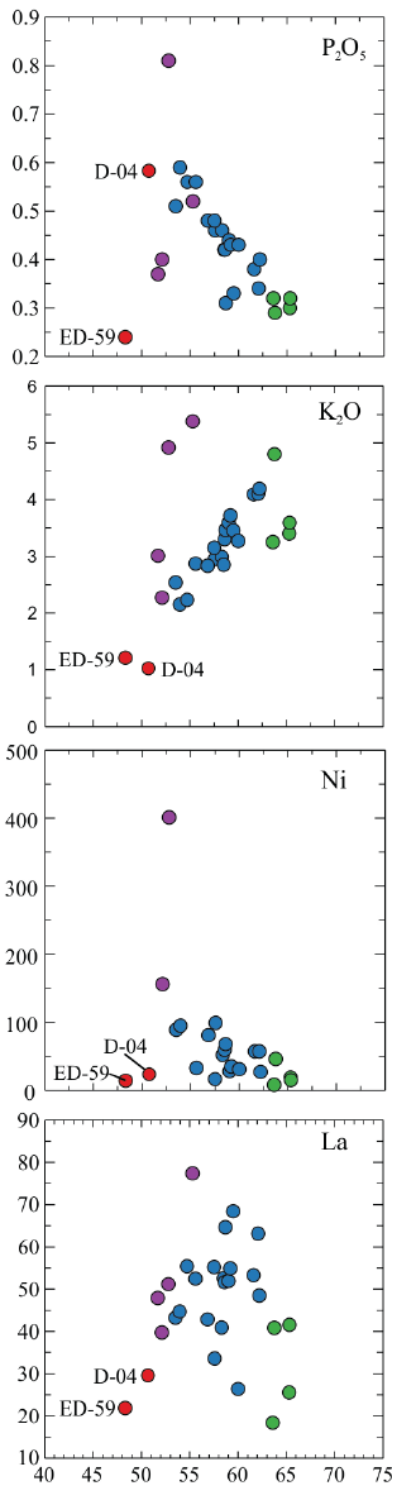

$\mathrm{SiO}_{2}$

Figure 8. Silica vs. oxides (wt.\%) and trace elements (ppm) variation plots (Harker-type diagrams) for the São João do Sabugi rocks. Symbols as in Figure 6. The analyzed gabbros are identified for further discussion. 
Braz. J. Geol. (2021), 51(2): e20200040
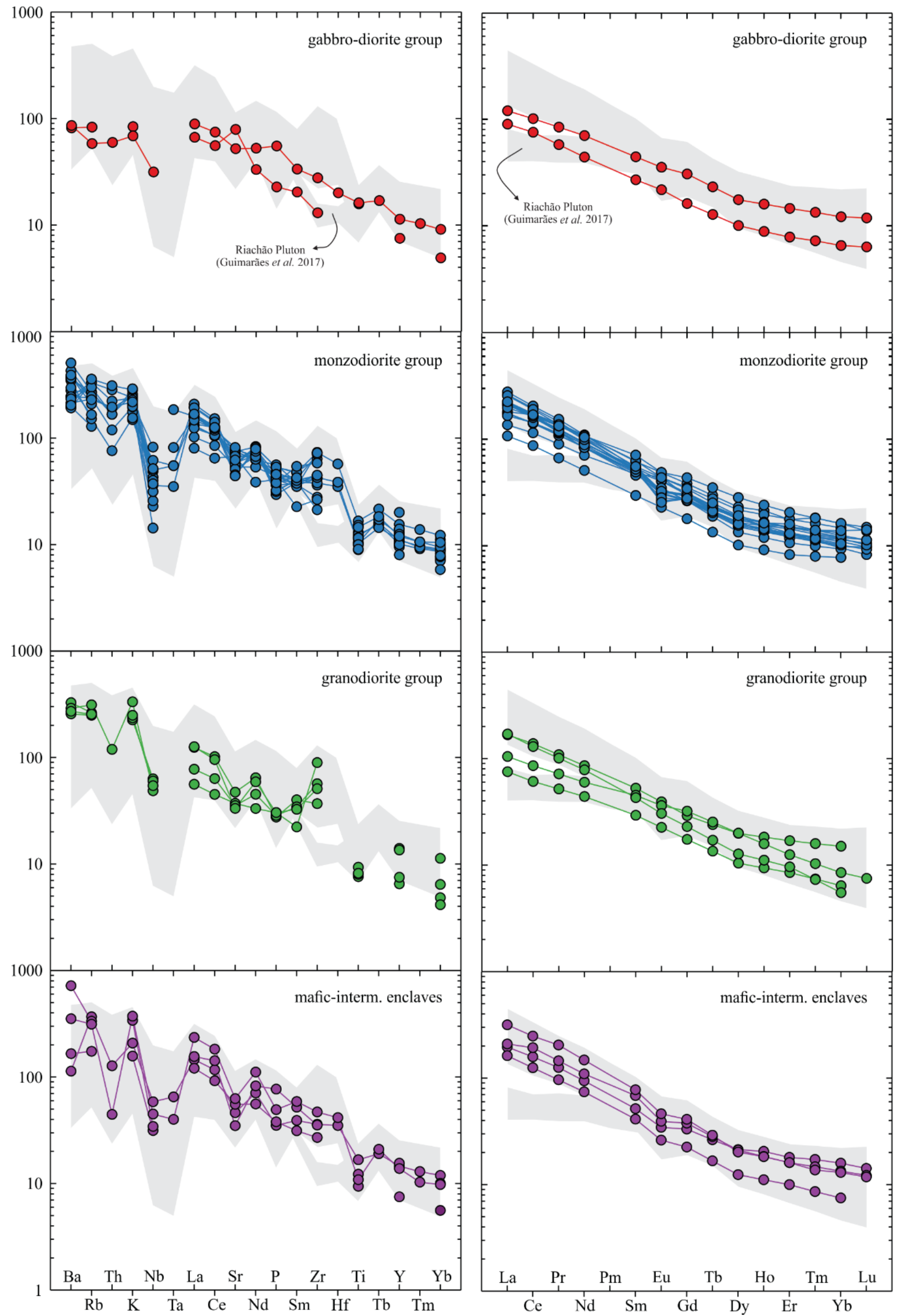

Figure 9. Chondrite-normalized multi-element spidergrams (Thompson 1982) and rare-earth element patterns (Evensen et al. 1978) for the São João do Sabugi rocks. Gray field: compositional ranges of the shoshonite suite in the Rio Piranhas-Seridó and São José do Campestre domains (references as in Figure 6) for comparison purposes. 
Table 2. Representative semi-quantitative chemical compositions of plagioclase, pyroxene, amphibole and biotite from monzodiorites of the São João do Sabugi Pluton.

\begin{tabular}{|c|c|c|c|c|c|c|c|c|c|c|c|c|}
\hline \multirow{2}{*}{$\begin{array}{l}\text { Mineral } \\
\text { Sample }\end{array}$} & \multicolumn{3}{|c|}{ Plagioclase } & \multicolumn{3}{|c|}{ Clinopyroxene } & \multicolumn{3}{|c|}{ Amphibole } & \multicolumn{3}{|c|}{ Biotite } \\
\hline & $\mathrm{D}-26 \mathrm{~B}$ & $\mathrm{D}-26 \mathrm{~B}$ & $\mathrm{D}-26 \mathrm{~B}$ & $\mathrm{D}-26 \mathrm{~B}$ & $\mathrm{D}-26 \mathrm{~B}$ & $\mathrm{D}-26 \mathrm{~B}$ & $\mathrm{D}-26 \mathrm{~B}$ & $\mathrm{D}-22.1$ & $\mathrm{D}-22.1$ & $\mathrm{D}-26 \mathrm{~B}$ & D-67 & D-46 \\
\hline Crystal & 1 & 2 & 6 & 20 & 26 & 29 & 17 & 31 & 32 & 11 & 41 & 50 \\
\hline $\mathrm{SiO}_{2}$ (wt.\%) & 64.31 & 62.00 & 64.41 & 53.44 & 58.64 & 59.86 & 54.23 & 45.49 & 46.72 & 41.47 & 39.84 & 40.68 \\
\hline $\mathrm{TiO}_{2}$ & $<\mathrm{dl}$ & $<\mathrm{dl}$ & $<\mathrm{dl}$ & 2.47 & $<\mathrm{dl}$ & $<\mathrm{dl}$ & 0.67 & 0.57 & 1.05 & 2.97 & 2.89 & 4.76 \\
\hline $\mathrm{Al}_{2} \mathrm{O}_{3}$ & 23.09 & 24.81 & 23.15 & 3.36 & 3.65 & 2.65 & 5.78 & 12.03 & 10.31 & 15.06 & 16.00 & 14.04 \\
\hline $\mathrm{FeO}$ & $<\mathrm{dl}$ & $<\mathrm{dl}$ & $<\mathrm{dl}$ & 9.48 & 10.07 & 9.15 & 9.67 & 19.40 & 18.20 & 13.91 & 19.95 & 16.26 \\
\hline $\mathrm{MnO}$ & $<\mathrm{dl}$ & $<\mathrm{dl}$ & $<\mathrm{dl}$ & $<\mathrm{dl}$ & $<\mathrm{dl}$ & $<\mathrm{dl}$ & $<\mathrm{dl}$ & $<\mathrm{dl}$ & 0.52 & $<\mathrm{dl}$ & $<\mathrm{dl}$ & $<\mathrm{dl}$ \\
\hline $\mathrm{MgO}$ & $<\mathrm{dl}$ & $<\mathrm{dl}$ & $<\mathrm{dl}$ & 14.79 & 17.00 & 17.28 & 15.85 & 7.83 & 8.80 & 14.20 & 8.85 & 11.81 \\
\hline $\mathrm{CaO}$ & 4.70 & 6.70 & 4.93 & 15.82 & 10.13 & 11.07 & 10.76 & 10.54 & 10.58 & $<\mathrm{dl}$ & $<\mathrm{dl}$ & $<\mathrm{dl}$ \\
\hline $\mathrm{Na}_{2} \mathrm{O}$ & 8.07 & 6.54 & 7.37 & 0.66 & 0.53 & $<\mathrm{dl}$ & 1.04 & 1.27 & 0.95 & $<\mathrm{dl}$ & $<\mathrm{dl}$ & $<\mathrm{dl}$ \\
\hline $\mathrm{K}_{2} \mathrm{O}$ & $<\mathrm{dl}$ & $<\mathrm{dl}$ & 0.14 & $<\mathrm{dl}$ & $<\mathrm{dl}$ & $<\mathrm{dl}$ & $<\mathrm{dl}$ & 1.23 & 1.17 & 8.07 & 8.26 & 8.19 \\
\hline $\mathrm{H}_{2} \mathrm{O}^{*}$ & - & - & - & - & - & - & 2.15 & 2.02 & 2.03 & 4.14 & 4.02 & 4.08 \\
\hline Total & 100.17 & 100.05 & 100.00 & 100.03 & 100.01 & 100.00 & 100.19 & 100.26 & 100.26 & 99.81 & 99.82 & 99.81 \\
\hline $\mathrm{Si}$ (cpfu) & 2.822 & 2.735 & 2.827 & 1.954 & 2.084 & 2.117 & 7.574 & 6.746 & 6.892 & 6.003 & 5.944 & 5.976 \\
\hline $\mathrm{Al}$ & 1.194 & 1.290 & 1.197 & 0.145 & 0.153 & 0.110 & 0.952 & 2.103 & 1.792 & 2.570 & 2.814 & 2.431 \\
\hline $\mathrm{Ti}$ & - & - & - & 0.068 & - & - & 0.070 & 0.064 & 0.116 & 0.323 & 0.325 & 0.526 \\
\hline $\mathrm{Fe}^{3+}$ & - & - & - & - & - & - & 0.259 & 0.332 & 0.356 & - & - & - \\
\hline $\mathrm{Fe}^{2+}$ & - & - & - & 0.290 & 0.299 & 0.271 & 0.846 & 2.025 & 1.843 & 1.684 & 2.489 & 1.997 \\
\hline $\mathrm{Mn}$ & - & - & - & - & - & - & - & - & 0.065 & 0.000 & 0.000 & 0.000 \\
\hline $\mathrm{Mg}$ & - & - & - & 0.806 & 0.900 & 0.911 & 3.299 & 1.731 & 1.936 & 3.064 & 1.968 & 2.587 \\
\hline $\mathrm{Ca}$ & 0.221 & 0.317 & 0.232 & 0.620 & 0.386 & 0.419 & 1.609 & 1.675 & 1.672 & 0.000 & 0.000 & 0.000 \\
\hline $\mathrm{Na}$ & 0.687 & 0.559 & 0.628 & 0.047 & 0.036 & - & 0.282 & 0.364 & 0.272 & 0.000 & 0.000 & 0.000 \\
\hline K & - & - & 0.008 & - & - & - & - & 0.232 & 0.220 & 1.490 & 1.572 & 1.534 \\
\hline$m g \#$ & - & - & - & 0.736 & 0.750 & 0.771 & 0.796 & 0.461 & 0.512 & 0.645 & 0.441 & 0.564 \\
\hline fe\# & - & - & - & 0.264 & 0.250 & 0.229 & 0.204 & 0.539 & 0.488 & 0.355 & 0.559 & 0.436 \\
\hline
\end{tabular}

< dl: below the detection limit; cpfu: cations per formula unit; *estimated after Tindle and Webb (1990); $m \nexists \#: \mathrm{Mg} /(\mathrm{Mg}+\mathrm{Fe}) ; f e \#: \mathrm{Fe} /(\mathrm{Fe}+\mathrm{Mg})$.

(A)

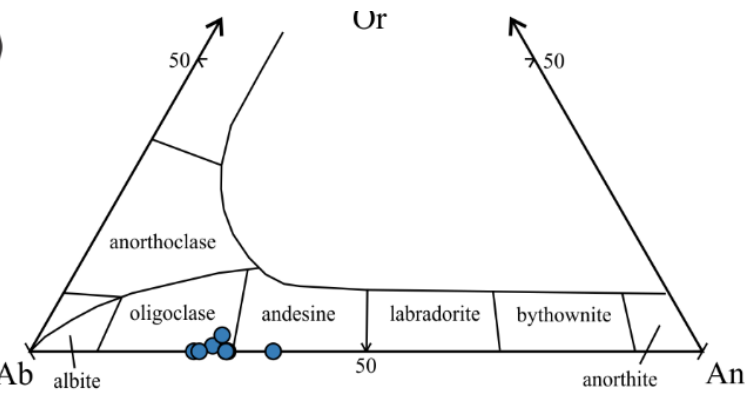

(C)

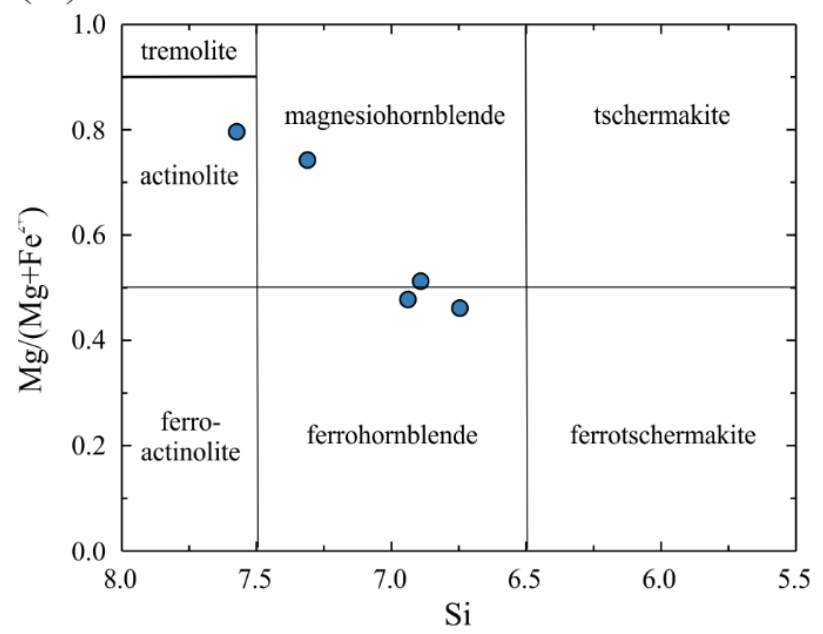

(B)

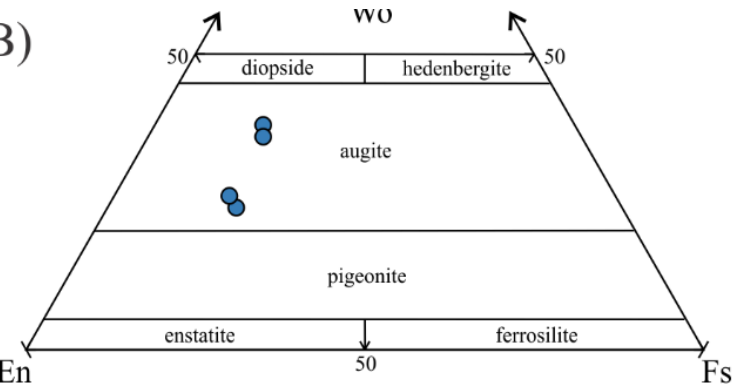

(D)

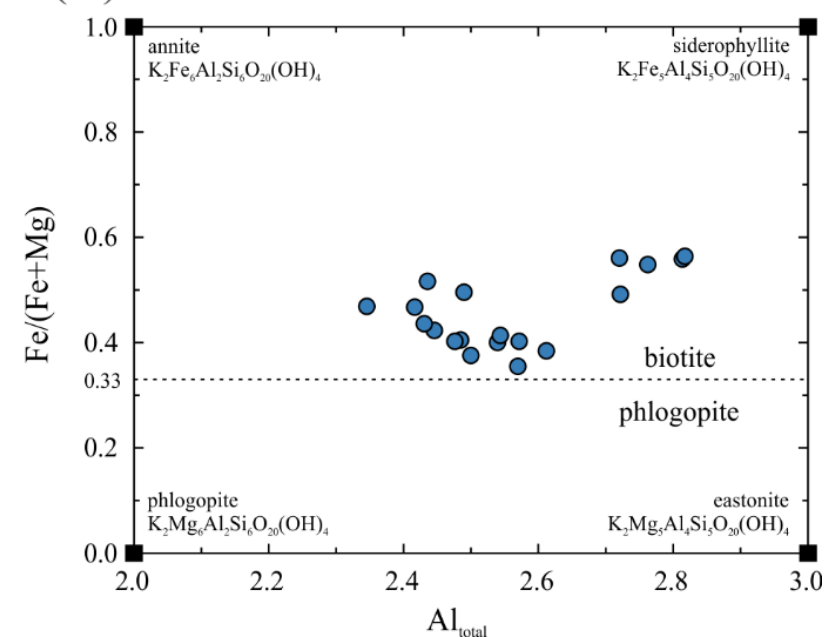

Figure 10. Mineral chemistry classification diagrams for felsic and mafic phases from the monzodiorites of the São João do Sabugi rocks. (A) Anorthite (An) - Albite (Ab) - Orthoclase (Or) molecular ternary plot (cf. Deer et al. 2013) for selected plagioclase crystals. (B) Ferrosilite (Fs) - Wollastonite (Wo) - Enstatite (En) molecular ternary plot (after Morimoto et al. 1988) for selected pyroxene crystals. (C) Si vs. $\mathrm{Mg} /\left(\mathrm{Mg}+\mathrm{Fe}^{2+}\right)$ cationic binary plot (after Leake et al. 1997) for representative amphibole crystals. (D) $\mathrm{Al}_{\text {total }} v s$. Fe/ $(\mathrm{Fe}+\mathrm{Mg})$ cationic binary plot (after Rieder et al. 1998) for representative biotite crystals. 
Ague (1997), using the $\mathrm{Al}$ contents measured in amphibole crystals from the monzodiorites (Tab. 2). Pressure estimates vary between 4.9 and $6.1 \mathrm{kbar}$, with an average of $5.4 \pm 0.5 \mathrm{kbar}$ (Tab. 3 ). A word of caution should be taken when interpreting these values, since they are based on semi-quantitative analyses with relatively high and undesirable uncertainties (see mineral chemistry section). Nevertheless, even when considering the associated analytical $2 \sigma$ error of $0.2 \mathrm{wt} . \%$ for $\mathrm{Al}$, the pressure range estimates are similar to those obtained by Campos et al. (2002) for the Rio Espinharas Shoshonitic Pluton, based on electron microprobe quantitative analyses of amphiboles (4.3-6.1 kbar; recalculated with the calibration of Ague 1997; Fig. 1). Moreover, they are also compatible with the occurrence of magmatic epidote in the SJSP monzodiorites ( $c f$. Schmidt and Thompson 1996, Sial et al. 2008). Lastly, the obtained estimates also coincide with the Ediacaran metamorphic peak in the studied region, considered to be transitional between upper amphibolite and granulite facies (3.8-5.7 kbar; Souza et al. 2006). These lines of evidence confirm the reliability of the obtained pressure estimates.

\section{Temperature}

The geothermometers Mg-in-liquid $\left(\mathrm{T}_{\text {Mg-in-liquid }}\right.$; Molina et al. 2015) and apatite saturation $\left(\mathrm{T}_{\text {satAp }}\right.$; Harrison and Watson 1984), the latter applied only for samples with $\mathrm{SiO}_{2}$ $>\sim 54$ wt.\% (Fig. 8), yielded temperatures between 904 and $1,101^{\circ} \mathrm{C}$ (Tab. 3), which are good estimates for $\mathrm{T}_{\text {liquidus }}$. Calculated temperatures are, on average, higher for enclaves $\left(1,034 \pm 59^{\circ} \mathrm{C}, \mathrm{n}=3\right)$ and gabbro-dioritic rocks $\left(1,008^{\circ} \mathrm{C}\right)$, and slightly lower for monzodioritic $\left(980 \pm 42^{\circ} \mathrm{C}, \mathrm{n}=18\right)$ and granodioritic rocks $\left(974 \pm 13^{\circ} \mathrm{C}, \mathrm{n}=4\right)$. The geothermometer of Ridolfi et al. (2010), based on the composition of monzodiorite calcic amphiboles, gave lower temperatures between 788 and $816^{\circ} \mathrm{C}\left(805 \pm 10^{\circ} \mathrm{C}, \mathrm{n}=4\right)$ that approach $\mathrm{T}_{\text {solidus }}\left(\mathrm{T}_{\mathrm{hbb}} ; \mathrm{Tab}\right.$. 3). As previously discussed for the Al-inhornblende pressure estimates, these semiquantitative temperature estimates should be interpreted with caution, even though they coincide with crystallization temperature estimates for the Rio Espinharas Shoshonitic Pluton $\left(700-898^{\circ} \mathrm{C}\right.$; Campos et al. 2002).

\section{Oxygen fugacity}

The presence of magnetite as the main Fe-Ti oxide, as well as the relatively low fe\# ratios $[\mathrm{Fe} /(\mathrm{Fe}+\mathrm{Mg})]$ of hornblende (0.2-0.54) and biotite (0.35-0.56) from the monzodiorites (Tab. 2), point to a relatively oxidized crystallization environment (cf. Anderson and Smith 1995, Anderson et al. 2008). As monzodiorites mostly follow the evolution trend of gabbro-diorites, we assume equivalent or slightly lower oxidation conditions for this last rock group. The $f_{\mathrm{O} 2}$ can be quantified from the amphibole composition using the oxybarometer of Ridolfi et al. (2010), corrected to the pressures previously obtained with the Al-in-hornblende barometer. The values of $\log \left(f_{\mathrm{O} 2}\right)$ are between -12.6 and -12.1 $\left(1.2<\Delta_{\mathrm{NNO}}<1.4\right.$; Tab. 3)

\section{DISCUSSION}

\section{Differentiation processes}

Jardim de Sá (1994) and Hollanda et al. (2003) emphasized that fractional crystallization is an important magma differentiation process for the shoshonitic suite in the RPS and SJC domains. However, they also argued that crustal contamination/assimilation and/or magma mixing can be secondary or even important processes in some plutons. Overall, Harker-type diagrams for the studied rocks (Fig. 8) point to fractional crystallization as an important differentiation process in the SJSP. In order to confirm this hypothesis, the analyzed samples were plotted in the bi-logarithmic variation diagram between compatible and incompatible elements of Figure 11A. Rubidium was chosen as incompatible, and Co as compatible element (Fig. 8). The SJSP samples define a trend of negative slope, reinforcing the role of fractional crystallization as a differentiation process ( $c f$. Cocherie 1986, Janoušek et al. 2016), which is also confirmed by the incompatible element variation diagram of Figure 11B (cf. Peccerillo et al. 2003, Schiano et al. 2010, Wang et al. 2013). However, major and trace-element modeling of pure fractional crystallization for the SJSP (not shown) yielded unreliably high crystallization rates $(\sim 80-83 \%)$, and several samples, mainly the monzodioritic rocks, plot away from the FC evolution vector, suggesting a certain degree of crustal assimilation in the SJSP magmatic evolution. In fact, Hollanda et al. (2003) stated that crustal

Table 3. Pressure, temperature and oxygen fugacity estimates for the São João do Sabugi rocks.

\begin{tabular}{|c|c|c|c|c|}
\hline Rock Groups & Gabbro-Diorites & Monzodiorites & Granodiorites & Enclaves \\
\hline \multicolumn{5}{|l|}{ Pressure } \\
\hline $\mathrm{P}_{\text {Al-in-hbl }}($ Ague 1997) & - & 4.9 - $6.1 \mathrm{kbar}$ & - & - \\
\hline \multicolumn{5}{|l|}{ Temperature } \\
\hline $\mathrm{T}_{\text {satAp }}($ Harrison and Watson 1984) & - & $900-981^{\circ} \mathrm{C}$ & $957-987^{\circ} \mathrm{C}$ & $929^{\circ} \mathrm{C}$ \\
\hline $\mathrm{T}_{\text {Mg-in-liquid }}($ Molina et al. 2015) & $1,001-1,008^{\circ} \mathrm{C}$ & $986-1,057^{\circ} \mathrm{C}$ & $962-1,000^{\circ} \mathrm{C}$ & $1,029-1,101^{\circ} \mathrm{C}$ \\
\hline $\mathrm{T}_{\mathrm{hbl}}($ Ridolfi et al. 2010) & - & $788-816^{\circ} \mathrm{C}$ & - & - \\
\hline \multicolumn{5}{|l|}{ Oxygen fugacity } \\
\hline $\log _{\mathrm{fO} 2}($ Ridolfi et al. 2010) & - & $-12.6-12.1$ & - & - \\
\hline$\Delta_{\mathrm{NNO}}$ & - & $1.2-1.4$ & - & - \\
\hline
\end{tabular}


assimilation may have occurred, at least, as secondary process during magma evolution of shoshonitic rocks from the RPS and SJC Domains. Moreover, field and petrographic evidences of open-system processes indicate that low-pressure crustal assimilation does have some importance for the SJSP evolution. These are mainly the common presence (primarily the monzodioritic facies) of partially digested xenoliths of Seridó Group paragneisses, schists and calc-silicate rocks (Figs. 4G, $4 \mathrm{H})$; and the presence of interstitial calcite in apparent equilibrium with igneous silicates in monzodiorite samples close to calc-silicate rock xenoliths (Fig. 5I). Similar textures are reported by Barnes et al. (2005) for the Hortavær Complex, Norway, where assimilation processes are dominant. These lines of evidence let us to consider the hypothesis of combined fractional crystallization and crustal assimilation (AFC) as an important differentiation process.
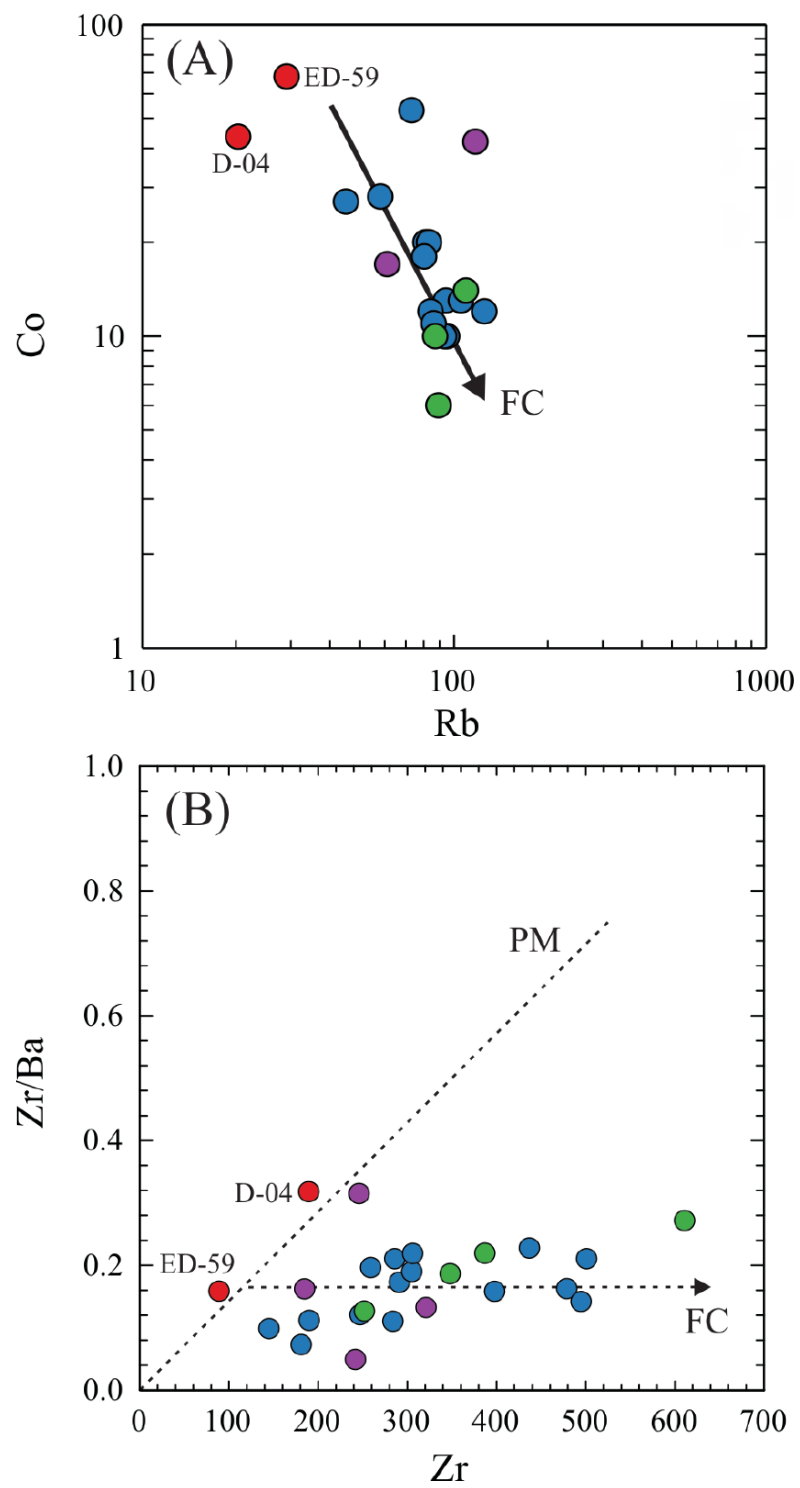

FC: fractional crystallization; PM: partial melting.

Figure 11. Trace element binary diagrams (in ppm) for the São João do Sabugi Pluton. (A) Incompatible ( $\mathrm{Rb})$ vs. compatible (Co) element bi-logarithmic diagram showing the major role of fractional crystallization in the magmatic evolution of the studied pluton. (B) $\mathrm{Zr}$ vs. $\mathrm{Zr} / \mathrm{Ba}$ (incompatible elements) pointing to the predominance of fractional crystallization processes over partial melting. Symbols as in Figure 6.
Of note, magma mixing processes as an evolutionary model for the SJSP were ruled out by Jardim de Sá (1994; see also Hollanda et al. 2003), since the studied body lacks granitic end members, as observed in other shoshonitic plutons where magma mixing is a plausible mechanism (e.g., Rio Espinharas pluton, Campos et al. 2002; Fig. 1). However, the common observation of irregular, elliptic and rounded mafic-intermediate enclaves and schlierens in the SJSP rocks and the chemical contrasts of these enclaves with the host rocks (Figs. 4E; 4F and 8) suggests that mechanical mixing and/or mingling (e.g., Macedo Filho and Souza 2016) between magmas with contrasting compositions may have occurred as an important process, though not well characterized so far. Moreover, replenishing of magmatic chamber by synplutonic mafic magma over an earlier crystal-rich granodiorite-tonalite magma can also contribute for some textural, petrographic and chemical features of the rocks studied (Castro 2013, Wiebe 2016).

Further major element least-square, mass-balance modeling was conducted with the spreadsheet OPTIMASBA (Cabero et al.2012). The modeling tested the hypothesis of derivation by AFC of the most evolved sample (daughter liquid) in the data set (sample AI-E; Jardim de Sá 1994; semi-quantitative modal composition: quartz $=24 \%$; oligoclase $=46 \%$; alkali feldspar $=12 \%$; biotite $=13 \%$; hornblende $=2 \%$; titanite $=$ $1 \%$; magnetite $=1 \%$; epidote, apatite and zircon $\sim 2 \%$ ) from the primitive (parent liquid) ED-59 (semi-quantitative modal composition: labradorite $=48 \%$, augite $=15 \%$, hypersthene $=$ $8 \%$, hornblende $=13 \%$, biotite $=8 \%$, magnetite $=3 \%$, titanite $=3 \%$, zircon and apatite $=2 \%$, alkali feldspar $<1 \%$ ), combined with variable assimilation rates of the local country-rocks: paragneisses, schists and calc-silicate rocks of the Seridó Group (analyses from Bezerra et al.2009 and our unpublished data). Note that, although the SJSP gabbro-diorites eventually have cumulatic textures ( $c f$. field aspects and petrography section), this is not the case of sample ED-59. The best result given in Table $4\left(\sum r^{2}=0.35\right)$ shows that it is possible to generate a daughter liquid with composition close to sample AI-E after $64 \%$ total crystallization of the parent ED-59 combined with assimilation of $\sim 25 \%$ ( $\mathrm{r}$ ratio $=0.28$, in which $\mathrm{r}=\mathrm{ma} / \mathrm{mc}$; ma $=$ amount of assimilated material; $\mathrm{mc}=$ amount of crystallized material) of a paragneiss represented by the sample 68.3 of Bezerra et al. (2009). Fractionated minerals are clinopyroxene (augite; 12\%), hornblende (14\%), plagioclase (labradorite; $46 \%)$, biotite $(6 \%)$, and magnetite (10\%).

The major element mass balance modeling was refined with trace elements using the spreadsheets PETROMODELER (Ersoy 2013) and FC-AFC-FCA and Mixing Modeler (Ersoy and Helvaci 2010). These spreadsheets provide a quantitative graphical-modeling of fractional crystallization (FC), combined (AFC) and decoupled (FCA) fractional crystallization and crustal assimilation, and magma mixing processes based on the equations of Rayleigh (1896), DePaolo (1981), Cribb and Barton (1996) and Powell (1984), respectively. Partition coefficients used in the calculations are those provided by the spreadsheets for basic rocks, complemented with values from the GERM database - "Geochemical Earth Reference Model", available at earthref.org/KDD. The AFC process was modeled 
for $r$ ratios between 0.2 and 0.3 , considering the lithotypes of the Seridó Group as contaminants and the fractionated minerals listed in Table 4. The best results were obtained with $r=0.3$, considering paragneisses and schists as assimilants. The influence of calc-silicate rocks in the AFC was negligible. Results are shown in Figure 12. The trace element AFC modeling agrees with the mass-balance results and is compatible with crystallization rates between $56-64 \%(r=0.3)$, which confirms the open-system geochemical differentiation and magma evolution of the SJSP, with assimilation of crustal components from the Seridó Group. In this scenario, it is plausible that the assimilation of metasediments by a basic magma in a chamber environment has contributed to a greater oxidation of the magma, as discussed in the oxygen fugacity section (Tab. 3). Furthermore, considering that the temperature estimates for the SJPS define a $\Delta \mathrm{T}$ of $\sim 200^{\circ} \mathrm{C}$ (Tab. 3) and the calculated pressures are almost invariable ( $\sim 5$ to $6 \mathrm{kbar}$; Tab. 3 ), it is argued that the assimilation process and the crystallization of the magmas that have built the SJSP took place in a relatively stationary magma chamber (isobaric evolution) at 19-24 km depth (for an average crustal density of $2.643 \mathrm{~g} / \mathrm{cm}^{3}$ ).

Values of ${ }^{87} \mathrm{Sr} /{ }^{86} \mathrm{Sr}$ ratios in the range $0.70766-0.70988$ and $\varepsilon_{\mathrm{Nd}}(580)$ between -13.5 and -17.8 reported by Hollanda et al. (2003) for the SJS are consistent with the hypothesis of crustal assimilation/contamination. However, the presence of multiple types of inclusions (metasedimentary host units, autoliths, microgranular enclaves) and eventual replenishing episodes within the magma chamber by hot mafic magmas (e.g., Castro 2013, Wiebe 2016) may account for the complexity of magma evolution of the studied shoshonitic series.

The SJSP is a syn- to post-collisional intrusion, and its emplacement was controlled by NE-trending, strike-slip shear zones related to the Brasiliano orogeny that affected the Borborema Province (e.g., Caby et al. 1991, Jardim de Sá 1994, Vauchez et al. 1995). This is confirmed by its age at $\sim 579 \mathrm{Ma}$ (zircon U-Pb ID-TIMS; Leterrier et al. 1994, Jardim de Sá 1994), and by the pervasive NE-SW striking foliation that aligns amphibole and biotite crystals, enclaves and xenoliths (Figs. 3D, 4F and 4G, 5G and 5H). Those are deep, continental scale structures, interpreted to be rooted mostly at the lithospheric mantle (e.g., Vauchez et al. 1995, Hollanda et al. 2003). Therefore, it seems plausible that such tectonic
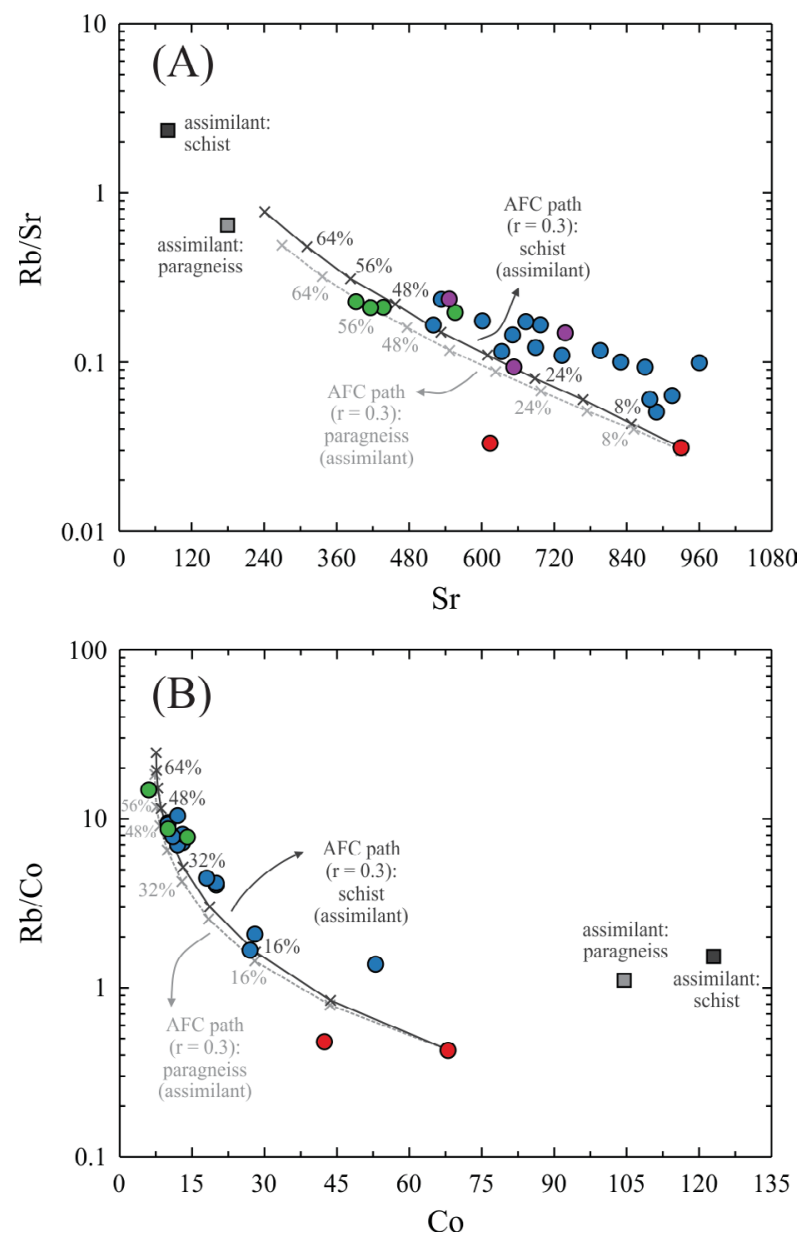

AFC: assimilation and fractional crystallization.

Figure 12. Trace element geochemical modeling of coupled assimilation and fractional crystallization magmatic process for the São João do Sabugi rocks. (A) Sr vs. Rb/Sr and (B) Co vs. Rb/ Co binary diagrams (in ppm) showing the modeled paths for the available data set for different metasedimentary contaminants from the Seridó Group (paragneiss: $\mathrm{Rb}=115.7, \mathrm{Sr}=189.4, \mathrm{Co}=$ 104.5 ppm; schist: $\mathrm{Rb}=188.5, \mathrm{Sr}=80.7$, $\mathrm{Co}=108.4$ ppm; our unpublished data). Symbols as in Figure 6.

Table 4. Major element least-square mass-balance assimilation and fractional crystallization geochemical modeling for the São João do Sabugi rocks.

\begin{tabular}{|c|c|c|c|c|c|c|c|c|c|}
\hline \multirow{2}{*}{$\begin{array}{l}\text { Liquid } \\
\text { compositions }\end{array}$} & \multirow[b]{2}{*}{$\mathbf{L}_{\mathbf{0}}$} & \multirow[b]{2}{*}{$L_{1}$} & \multirow[b]{2}{*}{$\mathbf{L}_{1}^{\prime}$} & \multirow[b]{2}{*}{ Contaminant $^{*}$} & \multicolumn{5}{|c|}{ Fractionated phases (wt.\%) after 64\% AFC, $\Sigma \mathbf{r}^{2}=0.35$} \\
\hline & & & & & $\operatorname{Pl}\left(\mathrm{An}_{52}\right)$ & Hbl & Bt & Cpx & Mt \\
\hline (wt. \%) & ED59 & AI-E & $64 \% \mathrm{AFC}$ & $\mathrm{r}=0.278$ & $46 \%$ & $14 \%$ & $6 \%$ & $12 \%$ & $10 \%$ \\
\hline $\mathrm{SiO}_{2}$ & 49.71 & 66.61 & 66.18 & 62.80 & 54.85 & 37.23 & 42.40 & 52.54 & 0.00 \\
\hline $\mathrm{TiO}_{2}$ & 1.69 & 0.85 & 0.91 & 0.91 & 0.81 & 0.97 & 3.15 & 2.43 & 6.05 \\
\hline $\mathrm{Al}_{2} \mathrm{O}_{3}$ & 16.68 & 15.88 & 15.81 & 16.28 & 27.73 & 14.54 & 15.38 & 1.67 & 1.01 \\
\hline $\mathrm{FeOt}$ & 13.55 & 4.90 & 4.86 & 7.76 & 0.03 & 27.85 & 18.03 & 9.00 & 92.73 \\
\hline $\mathrm{MgO}$ & 4.55 & 1.32 & 1.42 & 3.64 & 0.45 & 3.25 & 12.16 & 16.99 & 0.21 \\
\hline $\mathrm{CaO}$ & 9.15 & 3.03 & 2.93 & 2.53 & 10.63 & 12.22 & 0.00 & 16.72 & 0.00 \\
\hline $\mathrm{Na}_{2} \mathrm{O}$ & 3.20 & 3.65 & 3.75 & 3.14 & 5.22 & 1.18 & 0.00 & 0.65 & 0.00 \\
\hline $\mathrm{K}_{2} \mathrm{O}$ & 1.24 & 3.47 & 3.29 & 2.73 & 0.28 & 2.75 & 8.88 & 0.00 & 0.00 \\
\hline \multirow[t]{2}{*}{$\mathrm{P}_{2} \mathrm{O}_{5}$} & 0.25 & 0.31 & 0.84 & 0.21 & 0.00 & 0.00 & 0.00 & 0.00 & 0.00 \\
\hline & 100 & 100 & 100 & 100 & 100 & 100 & 100 & 100 & 100 \\
\hline
\end{tabular}

AFC: assimilation and fractional crystallization; Pl: plagioclase; Hbl: hornblende; Mt: magnetite; Cpx: clinopyroxene; Bt: biotite; Ttn: titanite; Ap: apatite; *paragneiss 68.3 (Bezerra et al. 2009). 
activity has also influenced the crustal assimilation episode that took place in the SJSP.

\section{Possible source}

Hollanda et al. (2003) presented and discussed isotopic and geochemical data for several shoshonitic plutons in the RPS and SJC domains, including some samples of the SJSP. Although they do not rule out crustal assimilation/contamination as a possible secondary evolutionary process, those authors argue that the chemical signatures of these rocks, marked by LILE- and light REE-enrichment, and negative $\mathrm{Nb}$ anomalies (Fig. 9), along with $\mathrm{Sr}$ radiogenic isotopic compositions $(0.71202-0.7059)$ and non-radiogenic $\mathrm{Nd}\left(-20.1<\varepsilon_{\mathrm{Nd}}(580)\right.$ $<-9.3)$, could be explained by partial melting of an enriched lithospheric mantle source metasomatized by percolation of subduction-related fluids during the Paleoproterozoic (e.g., metasomatized garnet lherzolite).

The spreadsheet PETROMODELER (Ersoy 2013) was used to test the possible generation of the less evolved SJSP compositions through partial melting of a metasomatized (enriched) lithospheric mantle. The modeling used the enriched mantle-1 (EM-1) composition represented by the sample RS1 from Menzies et al. (1987), a phlogopite- and pargasite-bearing lherzolite, following Souza et al. (2007) and Hollanda et al. (2003). Figure 13 shows partial melting curves for spinel-bearinglherzolite ( $5 \%$ spinel $c f$. Hollanda et al. 2003 and Souza et al. 2007) and garnet-bearing lherzolite (5\% garnet $c f$. Hollanda et al. 2003 and Souza et al. 2007). Results reveal that compositions akin to the ED-59 gabbro can be obtained after 18\% of modal dynamic partial melting (Langmuir et al. 1977) of a metasomatized garnet lherzolite source (Fig. 13). This overlaps with the results of Hollanda et al. (2003), which stated that moderate (10-20\%) partial melting of a similar enriched mantle source generated the precursor magmas of the shoshonitic suite in the RPS and SJC domains. In this scenario, the most evolved SJSP lithotypes evolved from the parent ED-59 by combined fractional crystallization and crustal assimilation, as summarized in the proposed evolution model for the SJS (Fig. 14). This model is consistent with the geological, petrographical, geochemical and isotopic features discussed above.

Evidences favoring an enriched source for the shoshonitic suite are also found in other bodies from the RPS and SJC domains. For instance, Souza et al. (2016) dated at $576 \pm 4$ $\mathrm{Ma}$ (zircon U-Pb LA-ICP-MS) an olivine-bearing leuconorite occurrence nearby the Poço Verde Pluton (Fig. 1). The authors presented chemical and isotopic data for this rock that point to a potassium enrichment episode of the metasomatized mantle source. Furthermore, the authors also obtained a Concordia age of $631 \pm 4 \mathrm{Ma}$ for the leuconorite which, along with an $\varepsilon_{\mathrm{Nd}(600)}$ of -16 , may indicate contamination of the basic magma with crustal material, as for the rocks here studied.

\section{CONCLUSIONS}

The SJSP is one of the most expressive occurrences of Ediacaran shoshonitic rocks in the RPS Domain, which makes it particularly interesting for petrogenetic studies on this magmatism within northeastern Borborema Province. Based on the geological, petrographic and chemical data presented here, the following conclusions are emphasized.

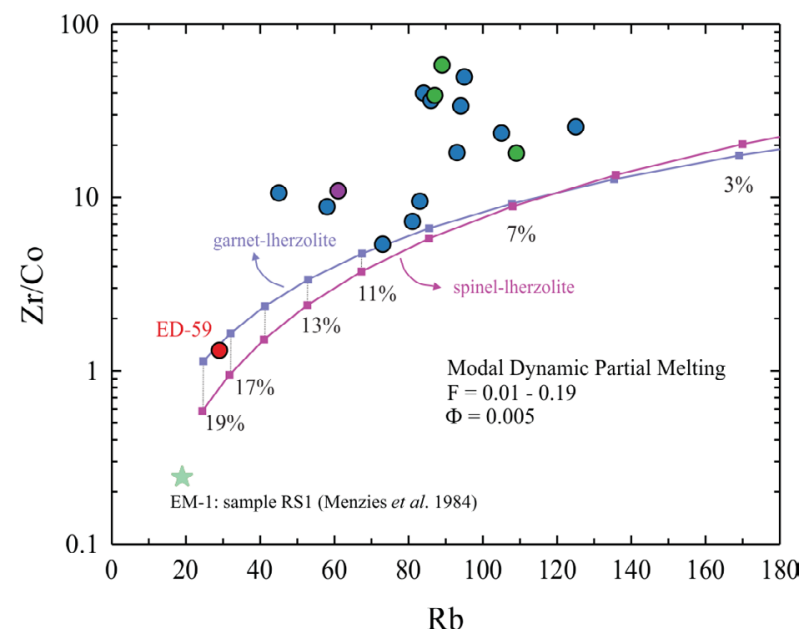

Figure 13. $\mathrm{Rb} v s . \mathrm{Zr} / \mathrm{Co}$ (in ppm) binary plot showing the modeling of modal dynamic partial melting (PM; Langmuir et al. 1977) of an enriched (metasomatized) mantle source (EM-1: $\mathrm{Rb}=19 ; \mathrm{Zr}=28$; Co $=115$ ppm; sample RS1 of Menzies et al. 1987, a pargasite- and phlogopite-bearing lherzolite) yielding compositions close the ED59 gabbro, assumed to represent the São João do Sabugi parental magma. Residue composition: olivine $(58 \%)$, orthopyroxene (23\%), clinopyroxene $(10 \%)$, pargasite $(2 \%)$, phlogopite $(2 \%)$, spinel $(0-5 \%)$, garnet $(0-5 \%)$. Symbols as in Figure 6.

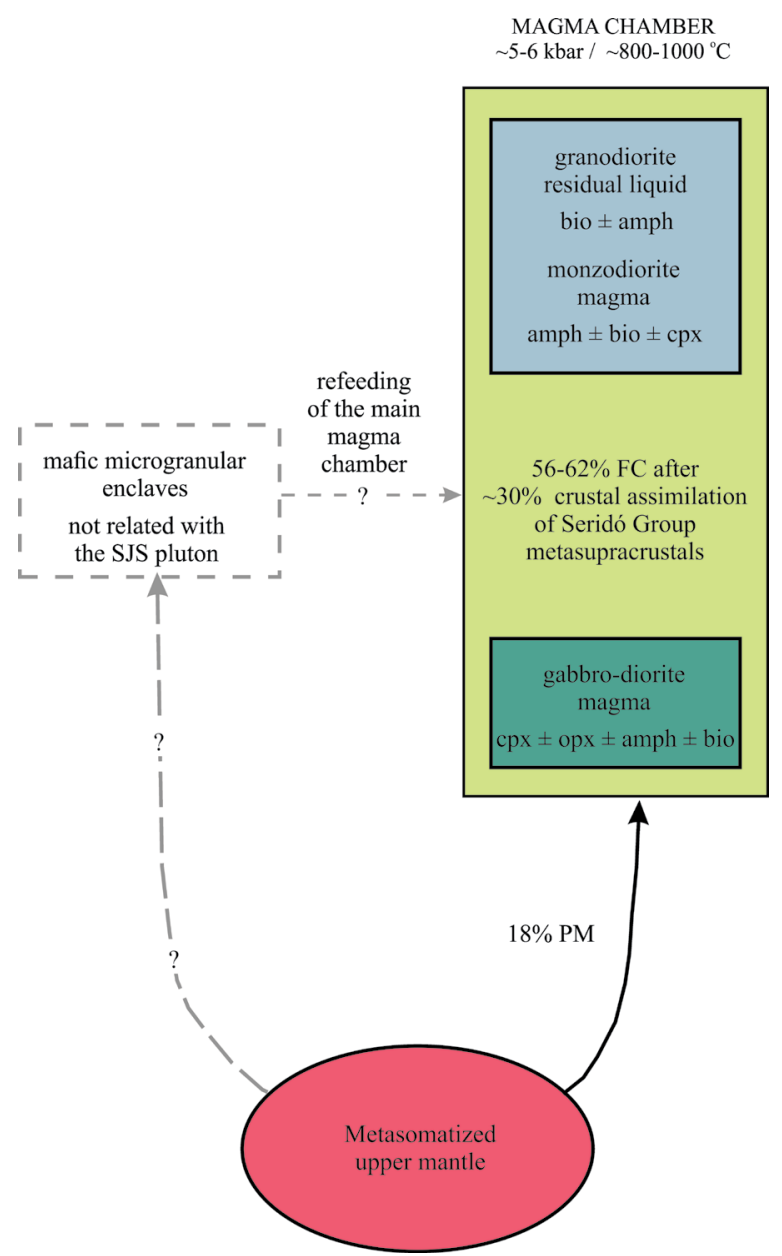

bio: biotite; amph: amphibole; cpx: clinopyroxene; opx: orthopyroxene; PM: partial melting; FC: fractional crystallization; SJS: São João do Sabugi Figure 14. Proposed evolution model for the São João do Sabugi pluton. 
- The SJSP is formed by three groups of rocks: gabbro-diorites (less evolved), monzodiorites (most voluminous unit) and granodiorites (more evolved).

- Several field and petrographic evidences point to open-system magmatic processes during the evolution of the SJSP. These include mafic-intermediate microgranular enclaves, partially digested xenoliths of local metasediments (Seridó Group), and the presence of interstitial calcite in apparent equilibrium with igneous silicates in monzodiorites hosting calc-silicate rock xenoliths.

- The less evolved gabbros, diorites and monzodiorites have hypersthene and augite as important mafic minerals, whereas the more evolved ones contain ferro- and magnesio-hornblende \pm biotite.

- These rocks are metaluminous to slightly peraluminous (granodiorites), have alkali-calcic and magnesian signatures and shoshonitic affinity, and show LILE (mainly $\mathrm{Ba}, \mathrm{Rb}, \mathrm{Th}$ and $\mathrm{K}$ ) and light REE enrichment, and negative $\mathrm{Nb}$ anomalies.

- Major and trace element geochemical modeling suggests that monzodioritic and granodioritic rocks derived from a gabbro-diorite liquid by fractional crystallization (56$64 \%$ ) associated with assimilation of $\sim 30 \%$ of crustal components from the Seridó Group.
- The SJSP magma emplacement has been controlled by post-orogenic reactivation of deep strike-slip shear zones in the Ediacaran. Assimilation and crystallization took place under relatively oxidizing conditions (close to the NNO buffer), pressures of 4.9-6.1 kbar and temperatures between $\sim 800$ and $1,000^{\circ} \mathrm{C}$, arguably in a relatively stationary magma chamber at depth.

- Modal dynamic partial melting $(\sim 18 \%)$ of an enriched lithospheric mantle source are responsible for the generation of the less evolved gabbro-diorite types.

\section{ACKNOWLEDGEMENTS}

The authors would like to thank the Programa de PósGraduação em Geodinâmica e Geofísica, Universidade Federal do Rio Grande do Norte (PPGG-UFRN) and the CNPq (grant 408607/2018-1, coordinator Z.S. Souza) for the logistical and financial support. The authors are also grateful to V.P. FREITAS and E.F. JARDIM DE SÁ for providing samples, geochemical data and petrographic thin sections. D.B.C. Paiva thanks CAPES Foundation for his Master of Science scholarship. Comments and suggestions by two anonymous reviewers helped to improve the original version of the manuscript and are much appreciated.

\section{ARTICLE INFORMATION}

Manuscript ID: 20200040. Received on: 05/22/2020. Approved on: 12/05/2020.

D.P. wrote the first draft of the manuscript and prepared all tables and Figures 1 to 13; F.V. supervised the scientific activity, revised and improved the manuscript and figures through corrections, recalculations, writing and suggestions; Z.S. revised and improved the manuscript, provided whole rock analysis, conducted geochemical modeling and prepared Figure 14. M.N. provided samples and data, helped with the EDX analysis and revised the manuscript.

Competing interests: The authors declare no competing interests.

\section{REFERENCES}

Ague J.J. 1997. Thermodynamic calculation of emplacement pressures for batholithic rocks, California: Implications for the aluminumin-hornblende barometer. Geology, 25(6):563-566. https://doi. org/10.1130/0091-7613(1997)025\%3C0563:TCOEPF\%3E2.3.CO;2

Almeida F.F.M., Hasui Y., Brito Neves B.B., Fuck H.A. 1981. Brazilian structural provinces. An introduction. Earth Science Reviews, 17(1-2):1-29. https://doi.org/10.1016/0012-8252(81)90003-9

Anderson J.L., Barth A.P., Wooden J.L., Mazdab F. 2008. Thermometers and thermobarometers in granitic systems. Reviews in Mineralogy and Geochemistry, 69(1):121-142. https://doi.org/10.2138/rmg.2008.69.4

Anderson J.L., Smith D.R. 1995. The effect of temperatures and oxygen fugacity on Al-in-hornblende barometry. American Mineralogist, 80(56):549-559. https://doi.org/10.2138/am-1995-5-614

Angelim L.D.A., Nesi J.R., Torres H.H.F., Medeiros V.C., Santos C.A., Veiga Junior J.P., Mendes V.A. 2006. Geologia e recursos minerais do Estado do Rio Grande do Norte. Escala 1:500.000. Recife: CPRM-Serviço Geológico do Brasil. 119 p + anexos. Available at: <http://rigeo.cprm.gov.br/jspui/ handle/doc/10234>. Accessed on: May 18, 2020.

Antunes A.F., Galindo A.C., Alves da Silva F.C., Jardim de Sá E.F., Lima R.F.S. 2000. Magmatismo granítico de afinidade subalcalina/monzonítica no Maciço São José do Campestre, Província Borborema (NE do Brasil): o exemplo do Pluton Monte das Gameleiras. Geochimica Brasiliensis, 14(1):5169. https://doi.org/10.21715/gb.v14i1.166
Barnes C.G., Prestvik T., Sundvoll B., Surratt D. 2005. Pervasive assimilation of carbonate and silicate rocks in the Hortavær igneous complex, north-central Norway. Lithos, 80(1-4):179-199. https://doi.org/10.1016/j.lithos.2003.11.002

Bezerra F.H.R., Amaral R.F.D., Silva F.O., Sousa M.O.L., Legrand J.M., Sá J.M., Maia H.N., Fonseca V.P., Vieira M.M., Souza L.C. 2009. Nota explicativa da folha Jardim do Seridó, SB. 24-ZBV. Rio Grande do Norte/ Paraíba: UFRN/CPRM. 85 p + anexos. Available at: <http://rigeo.cprm. gov.br/jspui/handle/doc/18296>. Accessed on: May 5, 2020.

Bonadiman C., Coltorti M., Siena F. 1994. Petrogenesis and T-fO estimates of Mt. Monzoni complex (Central Dolomites, Southern Alps): a Triassic shoshonitic intrusion in a transcurrent geodynamic setting. European Journal of Mineralogy, 6(6):943-966. https://www.schweizerbart.de/papers/ejm/list/6\#issue6

Burnham A.D., Berry A.J., Halse H.R., Schofield P.F., Cibin G., Mosselmans J.F.W. 2015. The oxidation state of europium in silicate melts as a function of oxygen fugacity, composition and temperature. Chemical Geology, 411:248259. https://doi.org/10.1016/j.chemgeo.2015.07.002

Cabero M.T., Mecoleta S., López-Moro F.J. 2012. OPTIMASBA: a Microsoft Excel workbook to optimise the mass-balance modelling applied to magmatic differentiation processes and subsolidus overprints. Computers and Geosciences, 42:206-211. https://doi.org/10.1016/j.cageo.2011.10.013

Caby R., Sial A.N., Arthaud M., Vauchez A. 1991. Crustal evolution and the Brasiliano orogeny in Northeast Brazil. In: Dallmeyer R.D., Lecorche J.P. (eds.). The west African orogens and circum-Atlantic correlatives. Berlin: Heidelberg, Springer, p. 373-397. 
Campos T.F.C., Neiva A.M.R., Nardi L.S.V. 2002. Geochemistry of the Rio Espinharas hybrid complex, northeastern Brazil. Lithos, 64(3-4):131-153. https://doi.org/10.1016/S0024-4937(02)00199-8

Castro A. 2013. Tonalite-granodiorite suites as cotectic systems: A review of experimental studies with applications to granitoid petrogenesis. Earth-Science Reviews, 124:68-95. https://doi.org/10.1016/j. earscirev.2013.05.006

Chagas C.F., Souza Z.S., Moreira J.A.M. 2018. Auréola termal provocada pela intrusão do pluton Totoró em micaxistos do Grupo Seridó, Ediacarano da Província Borborema, NE do Brasil. Geologia USP. Série Científica, 18(3):117-139. https://doi.org/10.11606/issn.2316-9095.v18-125724

Cocherie A. 1986. Systematic use of trace element distribution patters in log-log diagrams for plutonic suites. Geochimica et Cosmochimica Acta, 50(11):2517-2522. https://doi.org/10.1016/0016-7037(86)90034-7

Costa A.P., Cunha A.L.C., Cavalcante R., Dantas, A.R. 2018. Carta geológica-geofísica: folha SB.24-Z-B-IV Serra Negra do Norte. 1 mapa color. Escala 1:100.000. Recife: CPRM-Serviço Geológico do Brasil. Available at: <http://rigeo.cprm.gov.br/jspui/handle/doc/18555>. Accessed on: July 2, 2018.

Costa A.P., Dantas A.R. 2018. Geologia e recursos minerais da Folha Lajes SB. 24-XD-VI: estado do Rio Grande do Norte. Escala 1:100.000. Recife: CPRM-Serviço Geológico do Brasil, 163 p. Available at: <http://rigeo. cprm.gov.br/jspui/handle/doc/20238>. Accessed on: Nov. 22, 2018.

Cribb J.W., Barton M. 1996. Geochemical effects of decoupled fractional crystallization and crustal assimilation. Lithos, 37(4):293-307. https://doi. org/10.1016/0024-4937(95)00027-5

Deer W.A., Howie R.A., Zussman J. 2013. An introduction to the rock-forming minerals. London: Mineralogical Society, $498 \mathrm{p}$

DePaolo D.J. 1981. Trace element and isotopic effects of combined wallrock assimilation and fractional crystallization. Earth and Planetary Science Letters, 53(2):189-202. https://doi.org/10.1016/0012-821X(81)90153-9

Dias L.G.D.S. 2006. Caracterização geológica, geoquímica e geocronológica da suite plutônica enoproterozóica da região de Serrinha, porção centro-leste do maciço São José de Campestre, sudeste do RN. MS Dissertation, Programa de Pós-Graduação em Geodinâmica e Geofísica, Universidade Federal do Rio Grande do Norte, Natal, 203 p. https://repositorio.ufrn.br/ handle/123456789/18839

Ersoy Y. 2013. PETROMODELER (Petrological modeler): a Microsoft Excel spreadsheet program for modelling melting, mixing, crystallization and assimilation processes in magmatic systems. Turkish Journal of Earth Sciences, 22:115-125. https://doi.org/10.3906/yer-1104-6

Ersoy Y., Helvaci C. 2010. FC-AFC-FCA and mixing modeler: a Microsoft Excel $^{\odot}$ spreadsheet program for modeling geochemical differentiation of magma by crystal fractionation, crustal assimilation and mixing. Computers and Geosciences, 36(3):383-390. https://doi.org/10.1016/j. cageo.2009.06.007

Evensen N.M., Hamilton P.J., O'nions R.K. 1978. Rare-earth abundances in chondritic meteorites. Geochimica et Cosmochimica Acta, 42(8):1199-1212. https://doi.org/10.1016/0016-7037(78)90114-X

Foley S.F., Venturelli G., Green D.H., Toscani L. 1987. The ultrapotassic rocks: characteristics, classification and constraints for petrogenetic models. Earth-Science Reviews, 24(2):81-134. https://doi. org/10.1016/0012-8252(87)90001-8

Frost B.R., Barnes C.G., Collins W.J., Arculus R.J., Ellis D.J., Frost C.D. 2001. A chemical classification for granitic rocks. Journal of Petrology, 42(11):2033-2048. https://doi.org/10.1093/petrology/42.11.2033

Govindaraju K., Mevelle G. 1987. Fully automated dissolution and separation methods for inductively coupled plasma atomic emission spectrometry rock analysis. Application to the determination of rare earth elements. Plenary lecture. Journal of Analytical Atomic Spectrometry, 2:615621. https://doi.org/10.1039/JA9870200615

Guimarães I.P., Silva Filho A.F., Armstrong R. 2017. Origin and age of coeval gabbros and leucogranites in the northern subprovince of the Borborema Province, NE Brazil. Journal of South American Earth Sciences, 76:71-93. https://doi.org/10.1016/j.jsames.2017.02.014

Harrison T.M., Watson E.B. 1984. The behavior of apatite during crustal anatexis: equilibrium and kinetic considerations. Geochimica et Cosmochimica Acta, 48(7):1467-1477. https://doi.org/10.1016/0016-7037(84)90403-4
Hollanda M.H.B.M., Archanjo C.J., Bautista J.R., Souza L.C. 2015. Detrita zircon ages and Nd isotope compositions of the Seridó and Lavras da Mangabeira basins (Borborema Province, NE Brazil): Evidence for exhumation and recycling associated with a major shift in sedimentary provenance. Precambrian Research, 258:186-207. https://doi.org/10.1016/j.precamres.2014.12.009

Hollanda M.H.B.M., Archanjo C.J., Souza L.C., Dunyi L., Armstrong R. 2011. Long-lived paleoproterozoic granitic magmatism in the Seridó-Jaguaribe domain, Borborema Province-NE Brazil. Journal of South American Earth Sciences, 32(4):287-300. https://doi.org/10.1016/j.jsames.2011.02.008

Hollanda M.H.B.M., Jardim de Sá E.F., Trindade R.I.F., Alves da Silva F.C., Souza Z.S. 1999. O Pluton de Japi: geometria e modelo de intrusão de magmas granitóides em zonas extensionais. In: Simpósio Nacional de Estudos Tectônicos, 7., 1999, Lençóis. Proceedings..., v. 1, p. 81-83.

Hollanda M.H.B.M., Pimentel M.M., Jardim de Sá E.F. 2003. Paleoproterozoic subduction-related metasomatic signatures in the lithospheric mantle beneath NE Brazil: inferences from trace element and $\mathrm{Sr}-\mathrm{Nd}-\mathrm{Pb}$ isotopic composition of Neoproterozoic high-K igneous rocks. Journal of South American Earth Sciences, 15(8):885-900. https://doi. org/10.1016/S0895-9811(03)00014-2

Hoskin P.W., Kinny P.D., Wyborn D., Chappell B.W. 2000. Identifying accessory mineral saturation during differentiation in granitoid magmas: an integrated approach. Journal of Petrology, 41 (9):1365-1396. https://doi. org/10.1093/petrology/41.9.1365

Irvine T.N.J., Baragar W.R.A. 1971. A guide to the chemical classification of the common volcanic rocks. Canadian Journal of Earth Sciences, 8(5):523548. https://doi.org/10.1139/e71-055

Janoušek V., Moyen J.F., Martin H., Erban V., Farrow C. 2016. Geochemical modelling of igneous processes: principles and recipes in $\mathrm{R}$ language. Berlin: Springer, $346 \mathrm{p}$.

Jardim de Sá E.F. 1994. A Faixa Seridó (Província Borborema, NE do Brasil) o seu significado geodinâmico na Cadeia Brasiliana/Pan-Africana. PhD Thesis, Universidade de Brasília, Brasília, 762 p.

Langmuir C.H., Bender J.F., Bence A.E., Hanson G.N., Taylor S.R. 1977. Petrogenesis of basalts from the FAMOUS area: Mid-Atlantic Ridge. Earth and Planetary Science Letters, 36(1):133-156. https://doi. org/10.1016/0012-821X(77)90194-7

Leake B.E., Woolley A.R., Arps C.E.S., Birch W.D., Gilbert M.C., Grice J.D., Hawthorne F.C., Kato A., Kisch H.J., Krivovichev V.G., Linthout K., Laird J., Mandarino J.A., Maresch W.V., Nickel E.H., Rock N.M.S., Schumacher J.C., Smith D.C., Stephenson N.C.N, Ungaretti L., Whittaker E.J.W., Youzhi G. 1997. Nomenclature of amphiboles; report of the subcommittee on amphiboles of the International Mineralogical Association, Commission on New Minerals and Mineral Names. The Canadian Mineralogist, 35(1):219-246. https://pubs.geoscienceworld.org/canmin/ article/35/1/219/12862/Nomenclature-of-amphiboles-report-of-the

Leterrier J., Jardim de Sá E.F., Bertrand J.M., Pin C. 1994. Ages U-Pb sur Zircon de granitoïdes brasilianos de la ceinture de Seridó (Province Borborema, NE Brésil). Comptes rendus de l'Académie des sciences. Série 2 Sciences de la terre et des planètes, 318(11):1505-1511.

Macedo Filho A.A., Souza Z.S. 2016. Geoquímica do magmatismo Ediacarano Serra do Caramuru, NE da Província Borborema, RN, Brasil. Geologia USP. Série Científica, 16(3):117-142. https://doi.org/10.11606/ issn.2316-9095.v16i3p117-142

Menzies M., Rogers N., Tindle A., Hawkesworth C. 1987. Metasomatic and enrichment processes in lithospheric peridotites, an effect of asthenospherelithosphere interaction. In: Menzies M.K., Hawkesworth C.J. (Eds.). Mantle Metasomatism. London: Academic Press, p. 313-361. https://www.academia. edu/26431378/Metasomatic_and_enrichment_processes_in_lithospheric peridotites_an_effect_of_asthenosphere_lithosphere_interaction

Middlemost E.A. 1975. The basalt clan. Earth-Science Reviews, 11(4):337 364. https://doi.org/10.1016/0012-8252(75)90039-2

Middlemost E.A. 1994. Naming materials in the magma/igneous rock system. Earth-Science Reviews, 37(3-4):215-224. https://doi. org/10.1016/0012-8252(94)90029-9

Molina J.F., Moreno J.A., Castro A., Rodríguez C., Fershtater G.B. 2015 Calcic amphibole thermobarometry in metamorphic and igneous rocks: New calibrations based on plagioclase/amphibole Al-Si partitioning and amphibole/liquid $\mathrm{Mg}$ partitioning. Lithos, 232:286-305. https://doi. org/10.1016/j.lithos.2015.06.027 
Morimoto N., Fabries J., Ferguson A.K., Ginzburg I.V., Ross M., Seifert F.A., Zussman J., Aoki K., Gottardi G. 1988. Nomenclature of pyroxenes. Mineralogical Magazine, 52(367):535-550. https://doi.org/10.1180/ minmag.1988.052.367.15

Morrison G.W. 1980. Characteristics and tectonic setting of the shoshonite rock association. Lithos, 13(1):97-108. https://doi. org/10.1016/0024-4937(80)90067-5

Nardi L.V. 2016. Granitoides e séries magmáticas: o estudo contextualizado dos granitoides. Pesquisas em Geociências, 43(1):85-99. https://doi. org/10.22456/1807-9806.78194

Nascimento M.A.L., Antunes A.F., Galindo A.C., Jardim de Sá E.F., Souza Z.S. 2000. Geochemical signatures of the Brasiliano-age plutonism in the Serido belt, Northeastern Borborema Province (NE Brazil). Revista Brasileira de Geociências, 30(1):161-164. http://www.ppegeo.igc.usp.br/ index.php/rbg/article/view/10966/10420

Nascimento M.A.L., Galindo A.C., Medeiros V.C. 2015. Ediacaran to Cambrian magmatic suites in the Rio Grande do Norte domain, extreme Northeastern Borborema Province (NE of Brazil): Current knowledge. Journal of South American Earth Sciences, 58:281-299. https://doi. org/10.1016/j.jsames.2014.09.008

Nascimento M.A.L., Souza Z.S., Galindo A.C., Hollanda M.H.B.M., Pimentel M.M. 2002. Evidências de enriquecimento mantélico em rochas gabro-monzoníticas de Casserengue (PB) no extremo Nordeste da Província Borborema. Geochimica Brasiliensis, 16(1):31-40. https://doi. org/10.21715/gb.v16i1.498

Paiva D.B.C., Vilalva F.C.J., Nascimento M.A.L., Alves A. 2019. Petrografia e litoquímica de rochas gabroicas aflorantes a NE de São João do Sabugi, porção sul do estado do Rio Grande do Norte. In: Simpósio de Geologia do NE, 28., 2019, Aracaju, Brazil. Proceedings... p. 355-355. http://sbgeo. org.br/assets/admin/imgCk/files/Anais/Anais_28o_Simposio_de_ Geologia_do_Nordeste-ISBN.pdf

Pearce J.A. 1982. Trace Element Characteristics of Lavas from Destructive Plate Boundaries. In: Thorpe R.S. (Ed.). Andesites: orogenic andesites and related rocks. London: John Wiley, p. 252-548.

Peccerillo A., Barberio M.R., Yirgu G., Ayalew D., Barbieri M., Wu T.W. 2003. Relationship between mafic and peralkaline felsic magmatism in continental rift settings: a petrological, geochemical and isotopic study of the Gedemsa Volcano, Central Ethiopian Rift. Journal of Petrology, 44(11):2003-2032. https://doi.org/10.1093/petrology/egg068

Philpotts A., Ague J. 2009. Principles of Igneous and Metamorphic Petrology. 2. ed. Cambridge: Cambridge University Press, 667 p.

Powell R. 1984. Inversion of the assimilation and fractional crystallization (AFC) equations; characterization of contaminants from isotope and trace element relationships in volcanic suites. Journal of the Geological Society, 141(3):447-452. https://doi.org/10.1144/gsggs.141.3.0447

Rayleigh J.W.S. 1896. Theoretical considerations respecting the separation of gases by diffusion and similar processes. Philosophical Magazine, 42(259):493-498. https://doi.org/10.1080/14786449608620944

Ridolfi F., Renzulli A., Puerini M. 2010. Stability and chemical equilibrium of amphibole in calc-alkaline magmas: an overview, new thermobarometric formulations and application to subduction-related volcanoes. Contributions to Mineralogy and Petrology, 160:45-66. https://doi.org/10.1007/ s00410-009-0465-7

Rieder M., Cavazzini G., D’yakonov Y.S., Frank-Kamenetskii V.A., Gottardi G., Guggenheim S., Koval P.V., Müller G., Neiva A.M.R., Radoslovich E.W., Robert J-L., Sassi F.P., Takeda H., Weiss Z., Wones D.R. 1998. Nomenclature of the micas. Clays and Clay Minerals, 46:586-595. https:// doi.org/10.1346/CCMN.1998.0460513
Rudnick R.L., Gao S. 2003. Composition of the continental crust. Treatise on Geochemistry, 3:1-64. https://doi.org/10.1016/B0-08-043751-6/03016-4

Schiano P., Monzier M., Eissen J.P., Martin H., Koga K.T. 2010. Simple mixing as the major control of the evolution of volcanic suites in the Ecuadorian Andes. Contributions to Mineralogy and Petrology, 160:297-312. https://doi.org/10.1007/s00410-009-0478-2

Schmidt M.W., Thompson A.B. 1996. Epidote in calc-alkaline magmas: an experimental study of stability, phase relationships, and the role of epidote in magmatic evolution. American Mineralogy, 81 (3-4):462-474. https://doi. org/10.2138/am-1996-3-420

Shand S.J. 1943. The eruptive rocks. $2^{\text {nd }}$. ed. New York: Wiley, 444 p.

Shearer C.K., Papike J.J., Karner J.M. 2006. Pyroxene europium valence oxybarometer: Effects of pyroxene composition, melt composition, and crystallization kinetics. American Mineralogist, 91(10):1565-1573. https:// doi.org/10.2138/am.2006.2098

Sial A.N., Vasconcelos P.M., Ferreira V.P., Pessoa R.R., Brasilino R.G., Morais Neto J.M. 2008. Geochronological and mineralogical constraints on depth of emplacement and ascension rates of epidote-bearing magmas from northeastern Brazil. Lithos, 105(3-4):225-238. https://doi.org/10.1016/j. lithos.2008.04.002

Souza Z.S., Kalsbeek F., Deng X.D., Frei R., Kokfelt T.F., Dantas E.L., Li J.W., Pimentel M.M., Galindo A.C. 2016. Generation of continental crust in the northern part of the Borborema Province, northeastern Brazil, from Archaean to Neoproterozoic. Journal of South American Earth Sciences, 68:68-96. https://doi.org/10.1016/j.jsames.2015.10.006

Souza Z.S., Martin H., Peucat J.J., Jardim de Sá E.F., Macedo M.H.D.F. 2007. Calc-alkaline magmatism at the archean-proterozoic transition: the Caicó complex basement (NE Brazil). Journal of Petrology, 48(11):2149-2185. https://doi.org/10.1093/petrology/egm055

Souza Z.S., Montel J.M., Gioia S.M.L.C., Hollanda M.H.B.M., Nascimento M.A.L., Jardim de Sá E.F., Amaro V.E., Pimentel M., Lardeaux J.M., Veschambre M. 2006. Electron microprobe dating of monazite from high-T shear zones in the São José de Campestre Massif, NE Brazil. Gondwana Research, 9(4):441-455. https://doi.org/10.1016/j.gr.2005.11.008

Thompson R.N. 1982. Magmatism of the British Tertiary volcanic province. Scottish Journal of Geology, 18:49-107. https://doi.org/10.1144/ sig18010049

Tindle A.G., Webb P.C. 1990. Estimation of lithium contents in trioctahedral micas using microprobe data: application to micas from granitic rocks. European Journal of Mineralogy, 2(5):595-610.

Van Schmus W.R., Brito Neves B.B., Williams I.S., Hackspacher P.C., Fetter A.H., Dantas E.L., Babinski M. 2003. The Seridó Group of NE Brazil, a late Neoproterozoic pre-to syn-collisional basin in West Gondwana: insights from SHRIMP U-Pb detrital zircon ages and $\mathrm{Sm}-\mathrm{Nd}$ crustal residence (TDM) ages. Precambrian Research, 127(4):287-327. https://doi. org/10.1016/S0301-9268(03)00197-9

Vauchez A., Neves S., Caby R., Corsini M., Egydio-Silva M., Arthaud M., Amaro V. 1995. The Borborema shear zone system, NE Brazil. Journal of South American Earth Sciences, 8(3-4):247-266. https://doi. org/10.1016/0895-9811(95)00012-5

Wang W., Liu S., Bai X., Li Q. Yang P., Zhao Y., Zhang S., Guo R. 2013. Geochemistry and zircon $\mathrm{U}-\mathrm{Pb}-\mathrm{Hf}$ isotopes of the late Paleoproterozoic Jianping diorite-monzonite-syenite suite of the North China Craton: implications for petrogenesis and geodynamic setting. Lithos, 162-163:175194. https://doi.org/10.1016/j.lithos.2013.01.005

Wiebe R.A. 2016. Mafic replenishments into floored silicic magma chambers. American Mineralogist, 101(2):297-310. https://doi. org/10.2138/am-2016-5429 